\title{
Specific humoral response in cancer patients treated with a VEGF therapeutic vaccine under a compassionate use program
}

Javier Sánchez Ramírez ( $\sim$ javier.sanchez@cigb.edu.cu )

Centro de Ingenieria Genetica y Biotecnologia https://orcid.org/0000-0003-3263-5062

Yanelys Morera Díaz

Centro de Ingeniería Genética y Biotecnología

Mónica Bequet-Romero

Centro de Ingeniería Genética y Biotecnología

Francisco Hernández-Bernal

Centro de Ingeniería Genética y Biotecnología

Yenima Martín Bauta

Centro de Ingeniería Genética y Biotecnología

Katty-Hind Selman-Housein Bernal

Centro de Investigaciones Médico-Quirúrgicas

Ana Victoria de la Torre Santos

Hospital Celestino Hernández

Mariela Pérez de la Iglesia

Centro de Ingeniería Genética y Biotecnología

Lian Trimiño Lorenzo

Centro de Ingeniería Genética y Biotecnología

Team of Investigators of Compassionate use Program

Centro de Ingeniería Genética y Biotecnología

Marta Ayala Avila

Centro de Ingeniería Genética y Biotecnología

Research article

Keywords: CIGB-247, VEGF cancer vaccine, specific active immunotherapy, humoral response, compassionate use program, cancer patients

Posted Date: October 10th, 2019

DOI: https://doi.org/10.21203/rs.2.15817/v1 
License: (c) (i) This work is licensed under a Creative Commons Attribution 4.0 International License. Read Full License 


\section{Abstract}

Background: CIGB-247 is a cancer therapeutic vaccine that uses as antigen a variant of human vascular endothelial growth factor (VEGF) mixed with the bacterial-derived adjuvant VSSP. This VEGF vaccine has been evaluated in phase I clinical trials CENTAURO and CENTAURO-2, showing to be safe and immunogenic in advanced cancer patients selected under well-defined and controlled clinical conditions. Surviving patients were submitted to monthly re-immunizations and some of them showed objective clinical benefits. These observations led us to initiate a compassionate use program of CIGB-247 in patients who do not meet entry criteria applied for CENTAURO and CENTAURO-2 clinical trials.

Results: This report shows the characterization of the humoral response elicited after vaccination with $400 \mu \mathrm{g}$ of antigen combined with $200 \mu \mathrm{g}$ of VSSP in cancer patients representative of the Cuban real clinical practice setting. Polyclonal antibody response was specific to VEGF, and showed no cross reactivity with other VEGF family members like VEGF-C and VEGF-D. Specific IgM, IgA and IgG antibodies detected in the serum of vaccinated patients were able to block the binding of VEGF to its receptors VEGFR1 and VEGFR2. Serum-purified IgG fraction exhibited all these properties. For the first time, there is experimental evidence of the presence of polyclonal antibodies directed to clinically relevant epitopes on VEGF. These elicited antibodies impaired the high affinity interaction between VEGF and monoclonal antibody Bevacizumab, an antiangiogenic drug approved in combination with chemotherapy for the treatment of different tumors. This investigation also shows preliminary evidences of safety and immunogenicity of CIGB-247 in cancer patients under clinical conditions not yet explored.

Conclusions: CIGB-247 was immunogenic in a broader patient population, and induced Bevacizumab-like polyclonal antibodies, indicating that the VEGF-specific antibody response could have a potentially relevant clinical activity.

\section{Background}

Vascular endothelial growth factor (VEGF) has been broadly studied due to its relevant role in physiological and pathological angiogenesis [1]. Angiogenesis is the formation of new blood vessels from the existing vasculature, and it is significantly increased during tumor development with the aim to supply nutrients and oxygen that support the high rate proliferation of tumor cells. VEGF biological activity is mediated by its binding to VEGFR receptor 2 (VEGFR2) or VEGF receptor 1 (VEGFR1) [2], and both interactions have been implicated in tumor-induced angiogenesis and immunosuppression $[3,4]$.

All these properties made VEGF an attractive target for cancer immunotherapy. Passive and active immunotherapies targeted to this molecule have been developed, and they are currently in different stages of preclinical or clinical development. So far, the most successful passive immunotherapy directed to VEGF is Bevacizumab, a monoclonal antibody that neutralizes the binding of VEGF to its receptors [5], which has been approved, in combination with chemotherapy, for the treatment of different tumors [612]. 
VEGF-targeted active immunotherapies are based on different approaches, from DNA vaccines to peptide or protein-based vaccines $[13,14]$. Only the latter approach has reached evaluations in clinical studies. Wentink et al. developed a therapeutic vaccine that uses as antigen a truncated form of human VEGF (aminoacids 26-104). This antigen sequence represents the complete Bevacizumab binding site and using RFASE as adjuvant, the vaccine ( $\mathrm{hVEGF}_{26-104} / \mathrm{RFASE}$ ) induces an immune response with VEGF neutralizing activity and anti-tumor effect [15]. Elicited polyclonal antibody response in addition to its cross-reactivity with human VEGF, have also demonstrated in rats and monkeys its capacity to impair the binding of Bevacizumab to VEGF $[15,16]$, indicating the presence of antibodies that block binding sites on VEGF which have shown to be clinically relevant. This vaccine is being investigated in a phase I openlabel clinical trial (NCT02237638), and preliminary results of the first included patients indicated that hVEGF $_{26-104} /$ RFASE has a good safety profile. However, no VEGF-specific antibody responses were found in any of the patients evaluated [17].

On the other hand, our group has also developed a VEGF therapeutic vaccine (CIGB-247) that uses as antigen a recombinant mutated version of human VEGF genetically coupled to the first 47 aminoacids of p64K protein. Discrete mutations, included within the receptor-binding domain of VEGF, were made with the aim to block the binding between the antigen and VEGFR2, and hence avoid a potential proangiogenic activity [18]. The antigen is formulated with a bacterial-derived adjuvant obtained by solubilization of the outer membrane proteins of Neisseria meningitides to form very small sized proteoliposomes (VSSP) and the hydrophobic incorporation of the ganglioside NAcGM3 [19]. This vaccine candidate has shown antitumor and anti-metastatic effects in mice, stimulating the development of VEGF-blocking antibodies and specific $T$ cell response $[18,20]$. This vaccine formulation has been evaluated in two phase I clinical trials known as CENTAURO and CENTAURO-2, where safety and immunogenicity were studied in patients with advanced solid tumors [21, 22] selected under well-defined and controlled clinical conditions. The results obtained from these two clinical trials demonstrated the excellent safety profile of CIGB-247, and also indicated that it is possible to break immune self-tolerance through inducing a polyclonal antibody response against human VEGF, characterized by the presence of specific $\lg G$, IgM and IgA antibodies, the ability to inhibit the interaction between VEGF and its receptors, and the induction of a negative effect on VEGF bioavailability within platelet. Some of these properties investigated between one and three years of monthly re-immunizations are preserved with the singularity that as immunizations number increases, anti-VEGF IgG antibodies shift gradually from IgG1 to IgG4 [22, 23].

Patients enrolled in the CENTAURO clinical trial were in frank progression and they had previously received all available therapies and were no longer responding [21]. After the end of the trial period (week 16), these patients began to receive off-trial monthly re-immunizations with CIGB-247, and some of them showed objective clinical benefits $[23,24]$. This observation led us to initiate a compassionate use program (CUP) of CIGB-247 in cancer patients who do not meet strict entry criteria applied for CENTAURO and CENTAURO-2 clinical trials. A large part of cancer patients with life-threatening disease can be excluded from clinical trials; despite these subjects are better reflections of the real-world population of cancer patients [25]. The primary purpose of this CUP using CIGB-247 was to treat cancer 
patients with this VEGF therapeutic vaccine. However, the experience could provide an invaluable opportunity to continue evaluating the nature, magnitude, persistency and some elements of the safety profile of the induced humoral response in a broader cancer patient population. To achieve this, cancer patients were vaccinated with $400 \mu \mathrm{g}$ of antigen combined with $200 \mu \mathrm{g}$ of VSSP which represents the highest antigen dose that at that point of the initiation of this program had been found to be safe. Vaccination was administered until death, intolerance, marked disease progression or patient's withdrawal of consent. The present paper mainly describes and discusses the results of the humoral response obtained from this CUP of CIGB-247, and also shows a brief analysis of some safety aspects that could never have been studied under the rigid criteria applied for CENTAURO and CENTAURO-2 clinical trials.

\section{Methods}

Relevant information of all commercially available reagents was provided in Additional file 1.

\section{Investigational product}

The antigenused in this study is a recombinant fusion protein, representative of human VEGF isoform 121 (P64KhVEGF KDR $_{\text {- }}$ [18]. The lyophilized antigen was produced in vials of $400 \mu \mathrm{g}$ by the Development Unit of Center for Genetic Engineering and Biotechnology (CIGB, Havana, Cuba). The antigen was mixed with the adjuvant VSSP, very small sized particles obtained from the Neisseria meningitides outer membrane, supplied by the Center of Molecular Immunology (CIM, Havana, Cuba). Both, antigen and VSSP were produced under GMP conditions. At the moment of vaccination, one antigen vial was dissolved in pre-calculated amounts of injection water, and the required amount was mixed with the established quantity of VSSP $(200 \mu \mathrm{g})$, up to a final volume never exceeding $1 \mathrm{~mL}$ per injection dose.

\section{Compassionate use program (CUP)}

This CUP is a study of the CIGB-247 vaccine, and was conducted in accordance with the Regulation 632012 emitted by the Cuban Regulatory Authority (CECMED) [26]. This investigation was also performed in compliance with the ethical guidelines of the Declaration of Helsinki. All physicians who wanted to include patients in the CUP were required to contact the main coordinator of the study via e-mail (hernandez.bernal@cigb.edu.cu), attaching the following documents: (1) formal request letter asking the compassionate use of CIGB-247 and indicating that the patient received all available onco-specific therapies without response; (2) summary of the patient's medical record; (3) approval letter by institutional ethics committee. After that, the main coordinator send to the physician the informed consent form and other relevant information about the vaccine candidate (list of references, management of adverse events, safety profile). To participate in the CUP, all patients had to sign the informed consent form, after which the physician submitted the document through e-mail and send the following information: patient's full name, age, sex, type of cancer (solid tumor or hematologic malignancy), 
histopathological diagnosis, and the presence or not of metastases. In case of child participant, it was mandatory the assent from children (whenever possible) and a written informed consent from both parents or legal guardians. Once approved by the main coordinator, the patient was assigned a code, and the procedure of the vaccine preparation, immunization schedule and times of blood sampling were send to the physician by the main coordinator. Subsequently, the Center for Genetic Engineering and Biotechnology delivered the antigen and the adjuvant to the hospital for patient treatment. The physician was only obligated to report adverse events, probably or definitively related to the vaccine. Also, it was not mandatory the acquisition of blood samples.

\section{Patient inclusion criteria and immunization protocol}

CUP in Cuba included subjects of any sex and age, diagnosed with solid tumor or hematologic malignancy in advanced stages, with non-measurable or measurable lesions, metastasis free patients or individuals with metastatic disease of any localization. There was no restriction for Eastern Cooperative Oncology Group (ECOG) performance status, for chronic un-compensated diseases, autoimmune or immune suppressing diseases. Patients receiving immune modulator drugs, chemotherapy or biological therapies including active or passive immunotherapy were also recruited. Subjects with allergies to vaccine components, pregnancy or breast feeding, and evident mental incapacity to understand the information, deliver the consent, and act in consequence during the study were excluded.

One hundred fifty three patients were immunized with $400 \mu \mathrm{g}$ of antigen in combination with $200 \mu \mathrm{g}$ of the adjuvant VSSP, which represents the highest antigen dose that at that point of the initiation of this program had been found to be safe. All vaccinations were administered subcutaneously as a single site dose. Each patient received eight weekly vaccinations followed by a re-immunization on week twelve (induction phase). Four weeks after the ninth vaccination (week sixteen), re-immunizations were done once every four weeks, until death, intolerance, marked disease progression or patient's withdrawal of consent (re-immunization phase).

\section{Human blood samples}

Blood samples were obtained from 41 of the 153 vaccinated patients. Venous blood samples were collected using a blood collection set with pre-attached holder and taken into a serum separator tube for serum analyses. Serum samples were obtained as has been previously described [27, 28], and were immediately stored at $-20^{\circ} \mathrm{C}$ or $-70^{\circ} \mathrm{C}$ until use.

Blood samples were taken before initial vaccination (week 0 or pre-vaccination sample) and during the induction phase or re-immunization phase. For investigations conducted during both phases, blood samples were taken at different time points, depending on patient availability. 


\section{Biotinylation of monoclonal antibody Bevacizumab and VEGF binding testing}

To develop a competitive ELISA that measures the inhibition of the binding between VEGF and Bevacizumab, this monoclonal antibody was biotinylated. A Bevacizumab solution of $3.68 \mathrm{mg} / \mathrm{mL}$ was obtained in labelling buffer $\left(0.1 \mathrm{M} \mathrm{NaHCO}_{3}, 0.1 \mathrm{M} \mathrm{NaCl} \mathrm{pH} 8.5\right)$ by exchange chromatography. Biotin $\mathrm{N}-$ hydroxysuccinimide ester was added to Bevacizumab solution at a ratio of $0.1 \mathrm{mg}$ of biotin per $\mathrm{mg}$ of antibody. The reaction mixture was incubated with stirring during $4 \mathrm{~h}$ at room temperature. Free biotin was removed and antibody was exchanged into PBS by gel filtration. VEGF binding curves for Bevacizumab and biotinylated Bevacizumab yielded similar half maximal effective concentration $\left(\mathrm{EC}_{50}\right)$, indicating that conjugation did not affect the antigen- binding site (Additional file 2).

\section{ELISAs reagents}

Human VEGF isoform 121 (hVEGF ${ }_{\mathrm{CHO}}$ ) and human VEGF-C (hVEGF-C ${ }_{\mathrm{CHO}}$ ) were produced in $\mathrm{CHO}$ cells [29]. Plasmid construction and cell line development for hVEGF- $\mathrm{C}_{\mathrm{CHO}}$ are described in Additional file 3. HRP-conjugated goat anti-human IgG (Fc $Y$ fragment specific) antibody was used at $80 \mathrm{ng} / \mathrm{mL}$ for detecting human serum IgG. Biotinylated goat antibodies specific for human VEGFR2 or human VEGFR1 were used at $0.1 \mu \mathrm{g} / \mathrm{mL}$ for detecting VEGF/VEGFR2 or VEGF/VEGFR1 bindings respectively. Streptavidinperoxidase conjugate was used $1 / 30000$ or $1 / 35000$ dilution. Human serum, positive (PCS) and negative (NCS) for VEGF-specific IgG antibodies, have been previously used as assay controls [29].

\section{ELISA for specific anti-human VEGF IgG, IgM, IgA and IgE antibodies}

The levels of human IgG, IgM, IgA and IgE antibodies against VEGF were measured as described previously $[22,29]$. Briefly, wells were coated with $\mathrm{hVEGF}_{\mathrm{CHO}}$ during overnight incubation at $4^{\circ} \mathrm{C}$. Following blocking step, the wells were incubated with samples and $\lg \mathrm{G}, \lg \mathrm{M}, \lg \mathrm{A}$ or $\lg E$ antibodies were detected with HRP-conjugated goat anti-human IgG antibody, biotinylated goat anti-human IgM antibody, biotinylated anti-human IgA monoclonal antibody or biotinylated anti-human IgE monoclonal antibodies, respectively. For biotinylated conjugates the detection system consisted of streptavidin-conjugated HRP. Plates were developed by using $\mathrm{H}_{2} \mathrm{O}_{2}$ as substrate and TMB as chromogen.

IgG antibody titer was estimated as previously described [29]. The procedure was similar for $\lg M$, $\lg A$ and IgE with the difference that the interpolated value on " $x$ " axis was determined by adding five standard deviations to the duplicated mean of the blank optical density.

Titer ratio and "VEGF-specific antibody titer" were calculated as follow: 
[Due to technical limitations, this equation is only available as a download in the supplemental files section.] (A)

Specific antibody titer $=$ Post vaccination titer-Pre vaccination titer $(B)$

To declare a given sample taken during vaccination to be positive for VEGF-specific $\lg G$, $\lg \mathrm{M}$, $\lg$, or $\lg E$ antibodies, the obtained "titer ratio" must be $\geq 2$ (formula A). In the particular case of IgG antibodies, additionally to the criterion depicted above, for a sample to be considered positive, it has also to comply with a value of "specific antibody titer" $\geq 1 / 100$ (formula B).

The term seroconversion is only used in this paper for $\lg G$ antibodies and refers to a patient that has shown two or more samples positive for VEGF-specific antibodies during re-immunization phase (seroconverted patient) [21].

\section{IgG subclasses assays}

VEGF-specific IgG1, IgG2, IgG3, and IgG4 antibodies were determined as previously described [22]. Briefly, microtiter plates were coated with $\mathrm{hVEGF} \mathrm{CHO}_{\mathrm{O}}$ during overnight incubation at $4^{\circ} \mathrm{C}$. Following blocking step, sera were added and antigen-specific $\lg G 1, \lg G 2, \lg G 3$, and $\lg G 4$ antibodies were detected using biotinylated mouse monoclonal anti-human subclass-specific antibodies.

To declare a given serum sample taken during vaccination as "non-detectable" for VEGF-specific IgG1, IgG2, IgG3, or IgG4 antibodies, "specific antibody titer" must be $<1 / 10$. Values $\geq 1 / 10$ make samples to be classified as "detectable". For each patient, the IgG subclass classified as "detectable" with the highest "specific antibody titer" was declared as "predominant" [22].

\section{Competitive ELISA evaluating the blockade of the binding between VEGF and its receptors}

Competitive ELISA has been previously described in details by Sánchez et al. [22, 29]. Briefly, plates were coated with hVEGF ${ }_{\mathrm{CHO}}$ during overnight incubation at $4^{\circ} \mathrm{C}$. Following blocking step, sample was added and incubated for $1 \mathrm{~h}$ at $37^{\circ} \mathrm{C}$. Then, $100 \mu \mathrm{L}$ of $25 \mathrm{ng} / \mathrm{mL}$ of VEGFR2-Fc or $125 \mathrm{ng} / \mathrm{mL}$ of VEGFR1-Fc were added to the wells ( 12.5 and $62.5 \mathrm{ng} / \mathrm{mL}$ final concentration respectively) and additionally incubated for 45 min at $37^{\circ} \mathrm{C}$. After washes, wells were incubated with biotinylated anti-human VEGFR2 or VEGFR1 antibodies, the latter followed by streptavidin-peroxidase conjugate.

Maximum bindings of VEGFR2 or VEGFR1 were obtained from wells incubated with dilution buffer (instead of sample) and VEGF receptors/Fcy chimeras (VEGFR2-Fc or VEGFR1-Fc). The inhibition caused by a given sample on VEGF/VEGFR2 or VEGF/VEGFR1 interactions was expressed as percentage, according to the following formula: 
[Due to technical limitations, this equation is only available as a download in the supplemental files section.] (C) (D)

A given sample was considered positive for blocking activity when the value resulting from this ratio was $\geq 2$ (formula D). Patients showing at least one serum sample with neutralizing anti-VEGF antibodies during induction phase or re-immunization phase were considered with a positive blocking activity on the VEGF/VEGFR1 or VEGF/VEGFR2 bindings [21].

\section{Competitive ELISA evaluating the blockade of the interaction between VEGF and Bevacizumab}

Plates were coated with hVEGF ${ }_{\mathrm{CHO}}\left(1 \mu \mathrm{g} / \mathrm{mL}\right.$ in PBS, $100 \mu \mathrm{L} /$ well, overnight incubation at $\left.4^{\circ} \mathrm{C}\right)$. After three washes with $0.1 \%$ Tween 20 in PBS, the plates were blocked with $2.5 \%$ goat serum (v/v), $2 \%$ skim milk $(\mathrm{m} / \mathrm{v}), 0.05 \%$ Tween $20(\mathrm{v} / \mathrm{v})$ in PBS $\left(250 \mu \mathrm{L} /\right.$ well, $1 \mathrm{~h}$ at $\left.37^{\circ} \mathrm{C}\right)$. After a washing step, test sample or dilution buffer were added $\left(100 \mu \mathrm{L} /\right.$ well, $1 \mathrm{~h}$ at $\left.37^{\circ} \mathrm{C}\right)$. Then, $100 \mu \mathrm{L} /$ well of $7.6 \mathrm{ng} / \mathrm{mL}$ of biotinylated Bevacizumab antibody were added to the wells $(3.8 \mathrm{ng} / \mathrm{mL}$ final concentration and diluted in blocking buffer) and additionally incubated for $1 \mathrm{~h}$ at $37^{\circ} \mathrm{C}$. The maximum binding of Bevacizumab was obtained from incubated wells with dilution buffer (instead of sample) and biotinylated Bevacizumab. After washes, wells were incubated streptavidin-peroxidase conjugate (diluted 1:30 000 in 1\% BSA/PBS, 100 $\mu \mathrm{L} /$ well, $45 \mathrm{~min}$ at $37^{\circ} \mathrm{C}$ ). After washes, the subsequent steps of the reaction were developed as described in previous sub-sections.

Each plate included "blank" wells that were developed in parallel and did not receive neither test samples nor biotinylated bevacizumab, only dilution buffer. The other ELISA steps (antigen coating, adding blocking buffer, incubating with biotinylated antibody and streptavidin-peroxidase conjugate, adding substrate and stopping buffer) were performed as those for other wells.

The inhibition caused by a given sample on VEGF/Bevacizumab interaction was expressed as percentage, according to formula $\mathrm{C}$. The final concentration of $3.8 \mathrm{ng} / \mathrm{mL}$ corresponds to half maximal effective concentration $\left(\mathrm{EC}_{50}\right)$, and this value was obtained from four independent experiments (Additional file 4).

\section{ELISA for detecting human IgG antibodies specific to VEGF- $C$ and VEGF-D}

Two strategies were used for detecting human IgG antibodies specific to VEGF-C and VEGF-D. For the first one, wells were coated with a monoclonal antibody specific to myc-tagged proteins $(10 \mu \mathrm{g} / \mathrm{mL}$ in PBS, $100 \mu \mathrm{L} /$ well, overnight incubation at $\left.4^{\circ} \mathrm{C}\right)$. Following a washing step $(0.12 \%$ Tween $20 \mathrm{v} / \mathrm{v})$ and a blocking step $\left(2.5 \%\right.$ goat serum $v / v, 2 \%$ skim milk $\mathrm{m} / \mathrm{v}, 0.05 \%$ Tween $20 \mathrm{v} / \mathrm{v}$ in $\mathrm{PBS}, 250 \mu \mathrm{L} /$ well, $1 \mathrm{~h}$ at $\left.37^{\circ} \mathrm{C}\right)$, the 
wells were incubated with hVEGF-C ${ }_{\mathrm{CHO}}$ or hVEGF ${ }_{\mathrm{CHO}}(5 \mu \mathrm{g} / \mathrm{mL}$ in blocking buffer, $100 \mu \mathrm{L} /$ well, $1 \mathrm{~h}$ at $37^{\circ} \mathrm{C}$ ). Plates were washed, and test samples were added (diluted in blocking buffer, $100 \mu \mathrm{L} / \mathrm{well}, 1 \mathrm{~h}$ at $37^{\circ} \mathrm{C}$ ). Specific IgG antibodies were detected with HRP-conjugated goat anti-human IgG antibody (diluted in $2 \%$ skim milk v/v in PBS, $100 \mu \mathrm{L} /$ well, $1 \mathrm{~h}$ at $37^{\circ} \mathrm{C}$ ). Plates were developed by using $\mathrm{H}_{2} \mathrm{O}_{2}$ as substrate and TMB as chromogen ( $100 \mu \mathrm{L} /$ well, 10 minutes at room temperature). The reaction was stopped by the addition of $2.0 \mathrm{~N} \mathrm{H}_{2} \mathrm{SO}_{4}(50 \mu \mathrm{l} /$ well), and the absorbance was measured at $450 \mathrm{~nm}$.

For the second strategy, VEGF-C or VEGF-D $\left(2.5 \mu \mathrm{g} / \mathrm{mL}\right.$ in PBS, $100 \mu \mathrm{L} /$ well, overnight incubation at $\left.4^{\circ} \mathrm{C}\right)$ were added to Histidine-select nickel coated high sensitivity multiwell plates. After a washing step $(0.05 \%$ Tween $20 \mathrm{v} / \mathrm{v}$ in PBS), test samples were added (diluted in 0.05\% skim milk v/v, 0.05\% Tween 20 in PBS, $100 \mu \mathrm{L} /$ well, $2 \mathrm{~h}$ at $37^{\circ} \mathrm{C}$ ), and specific IgG antibodies were detected with HRP-conjugated goat anti-human IgG antibody (diluted in $0.05 \%$ skim milk v/v, $0.05 \%$ Tween 20 in PBS). The subsequent steps of the reaction were developed as previously described. Recombinant human VEGF receptor $3 /$ Fcy chimera was used as assay positive control.

\section{IgG fraction purification}

Post-vaccination sera from different patients and positive for VEGF-specific IgG antibody titer were pooled, and IgG from serum was purified by protein A. Lipoproteins were removed by adding solid PVP to the serum to a final concentration of $3 \%(\mathrm{w} / \mathrm{v})$. After $4 \mathrm{~h}$ at $4^{\circ} \mathrm{C}$, sample was centrifuged at $15700 \mathrm{~g}$ for 30 min at $4^{\circ} \mathrm{C}$. Supernatant was removed and exchanged into $0.02 \mathrm{M}$ sodium phosphate buffer $\mathrm{pH} 7$ (binding buffer) using a desalting column. After centrifugation, supernatant was mixed to a preequilibrated protein A sepharose media, and later incubated during $14-16 \mathrm{~h}$ at $4^{\circ} \mathrm{C}$ with stirring. The gel bed was added to an empty column, and the excess fluid was allowed to drain via gravity. The gel bed was washed with binding buffer, and the IgG fraction was eluted $0.1 \mathrm{M}$ glycine buffer $\mathrm{pH}$ 2.7. The IgG fraction was collected into a neutralization buffer $(1 \mathrm{M}$ Tris- $\mathrm{HCl} \mathrm{pH} \mathrm{9)}$. The eluate was immediately exchanged into PBS, concentrated between $10-20 \mathrm{mg} / \mathrm{mL}$ of $\mathrm{IgG}$, and the final sample was stored at $70^{\circ} \mathrm{C}$ until use (IgG comp). A purified human IgG isolated from pooled normal human serum (IgG neg) was used as assay negative control.

\section{Results}

\section{Characteristics of the patients evaluated during the humoral response study}

Table 1 shows the basic characteristics of the 41 patients with at least one serum sample available for the humoral response study. These cancer patients had pre and post-vaccination serum samples that allowed the evaluation of the humoral response elicited by CIGB-247. 
Of the forty-one patients, 25 were females and 16 males (Table 1 ). Subjects had a variety of malignancies at original diagnosis, being the most common ovary cancer ( $n=9$ for a $22 \%$ ). At the moment of inclusion in the CUP, 27 patients (66\%) had metastatic disease in some cases localized at multiple sites.

\section{Antibody classes responses specific to VEGF and VEGF blocking activities of patients' serum after induction phase}

In order to evaluate the vaccine-induced polyclonal humoral immune response, $\lg \mathrm{G}, \lg \mathrm{M}, \lg \mathrm{A}$ and $\lg \mathrm{E}$ antibodies specific to VEGF were assessed by ELISA. Thirty-two patients had at least one serum sample belonging to the induction phase. Figure 1a displays specific antibody titers against VEGF for IgG, IgM, and IgA respectively in these subjects. Each patient is represented as an empty symbol (serum sample positive for antibody) or filled symbol (serum sample negative for antibody). It can be seen that of the 32 evaluated patients, 26 individuals (81.3\%) had positive samples to VEGF-specific IgG antibodies, 14 (43.8\%) for IgA, and 11 (34.8\%) for IgM. No patient had detectable levels of VEGF-specific IgE antibodies during the induction phase (Additional file 5). Specific $\lg G$ antibodies were found in the highest number of patients, and this type of immunoglobulins showed the highest antibody titers (Fig. 1a).

After induction phase, there were nine patients with triple-positive sample $\left(\operatorname{lgG}^{+} / \operatorname{lgM}{ }^{+} / \lg A^{+}\right)$, five patients with $\operatorname{lgG}^{+} / \operatorname{lgA}^{+}$double-positive sample and two patients with $\operatorname{lgG}^{+} / \operatorname{lgM}^{+}$double-positive sample. The combination $\lg \mathrm{M}^{+} / \lg \mathrm{A}^{+}$double-positive sample was not observed, and all cases with single-positive sample were IgG (10 patients). The single-positive sample for IgM or IgA was not detected. The remaining 6 individuals were triple-negative sample $\left(\operatorname{lgG}^{-1} \lg M^{-} / \lg A^{-}\right)$(Additional file 5).

The binding of VEGF to its receptors, VEGFR2 and VEGFR1, is involved in relevant steps for tumor progression including tumor angiogenesis and tumor-induced immunosuppression [30]. In order to investigate the ability of vaccine-elicited antibodies to block VEGF/VEGFR1 and VEGF/VEGFR2 bindings, a competitive ELISA was performed. Figure $1 \mathrm{~b}$ shows the number of patients with positive blocking activity on the bindings VEGF/VEGFR2 or VEGF/VEGFR1. Individuals showing at least one serum sample with neutralizing anti-VEGF antibodies were considered positive for blocking activity. Of the 31 available patients and during induction phase, 17 patients (54.8\%) had a positive blocking activity on the interactions VEGF/VEGFR2 or VEGF/VEGFR1. Among these patients, 9 subjects (29\%) developed a polyclonal antibody response with the ability to simultaneously block the bindings VEGF/VEGFR2 and VEGF/VEGFR1 (dual blocking activity).

These results demonstrate that vaccination with $400 \mu \mathrm{g}$ of antigen in combination with $200 \mu \mathrm{g}$ of VSSP induces a polyclonal antibody response formed by VEGF-specific IgG antibodies as predominant immunoglobulin, but also IgM and IgA antibodies can be detected. Elicited antibodies also block the interaction between VEGF and its receptors VEGFR1 and VEGFR2. 


\section{Specific anti-VEGF IgG seroconversion and VEGF blocking activities of patients' serum during re-immunization phase}

Patients were immunologically monitored at different time points during re-immunization phase, from week 16 to week 135 ( $\approx 2.8$ years). Re-immunizations were administered every four weeks. In order to investigate whether repetitive vaccinations help to keep a systemic humoral response directed to human VEGF, IgG seroconversion and blocking activity were analyzed in serum samples of vaccinated patients.

Of the thirty patients that were immunized during the re-immunization phase, twenty individuals had at least two serum samples after week 16 . Among these patients, eleven patients (55\%) were classified as seroconverted for VEGF-specific IgG antibodies, while the remaining patients (45\%) did not achieve this status (Fig. 2a).

Serum samples from thirty patients were available for analysis of the blocking activity against the binding between VEGF and its receptors. Among these patients, nineteen (63.3\%) or seventeen $(56.7 \%)$ individuals showed a positive blocking activity for VEGF/VEGFR2 or VEGF/VEGFR1 interactions, respectively. Among these patients, ten individuals (33.3\%) had dual blocking activity (Fig. 2b).

\section{IgG subclasses}

Within the polyclonal antibody response directed to VEGF, IgG is the principal immunoglobulin. In order to study the contribution of each one of the four VEGF-specific IgG subclasses, indirect ELISA was performed using human VEGF as coating antigen. Figure 3 shows IgG subclasses analysis for four different vaccination periods: weeks 6-12, weeks 16-48 (up to one year), weeks 49-96 (up to 2 years) and weeks 97-144 (up to 3 years). In each of these periods, available serum samples classified as positive for VEGF-specific IgG antibodies were chosen for these measurements. IgG1, IgG2, IgG3 and IgG4 subclasses specific to VEGF were found in all periods. IgG1 was the predominant subclass during the induction phase, accounting for $70 \%$ of the available serum samples, and IgG3 was the second most important immunoglobulin with $20 \%$ (Fig. 3). Between weeks 16-48, IgG3 and IgG4 subclasses were the predominant subclasses with $43 \%$ of the available serum samples. However, IgG1 was become the predominant subclasses between weeks $49-96$, accounting for $53 \%$ of the available serum samples, and IgG4 was the second most important immunoglobulin with $27 \%$. After two years or repetitive immunizations, between weeks $97-144$, IgG4 was the predominant subclasswith $43 \%$ of the available serum samples (Fig. 3).

\section{Properties of the IgG fraction purified from de serum of vaccinated patients}


In order to know whether the immunological properties detected in immune serum (specificity for VEGF and blocking activity) are observed within the IgG fraction, post-vaccination serum samples classified as positive for VEGF- specific IgG antibodies were pooled, and then, IgG immunoglobulins were purified (IgG comp).

Immobilized VEGF was recognized for IgG comp and also for assay positive controls (Bevacizumab and PCS). Low levels of basal binding were observed for IgG neg and NCS (Fig. 4a). For the interaction between immobilized VEGF and VEGFR2, IgG comp exhibited an inhibition value of $29.88 \%$, while IgG neg, at the same total IgG concentration, showed an inhibition value of $11.70 \%$ (Fig. 4b). For the binding VEGF/VEGFR1, IgG comp exhibited an inhibition value of $28.98 \%$, while IgG neg, at the same total IgG concentration, showed an inhibition value of $14.20 \%$ (Fig. 4c). Therefore, a positive blocking activity on the interaction between VEGF and its receptors was detected for IgG comp, showing, in both cases, inhibition levels greater than 2 (see equation D). Both competitive ELISAs used Bevacizumab as assay positive control at different concentrations, indicating that the test is able to detect changes on inhibition percentages.

The functional VEGF epitope for Bevacizumab binding has proven to be clinically relevant. In order to investigate whether the polyclonal response elicited by CIGB-247 includes antibodies able to block this relevant epitope through the competition against Bevacizumab for the same sites on VEGF or by steric hindrance, a competitive ELISA was developed using this monoclonal antibody as competitor. IgG neg showed an inhibition value of $1.51 \%$, while IgG comp, at the same total IgG concentration, showed an inhibition value of $13.06 \%$ (Fig. 4d). Therefore, a positive blocking activity on the interaction VEGF/Bevacizumab was observed for IgG comp, showing inhibition levels greater than 2 .

All results presented so far indicate that those immunological properties described for serum of vaccinated cancer patients such as specificity for VEGF and dual blocking activity can be found within serum IgG fraction. As additional element, the polyclonal response is formed by Bevacizumab-like antibodies.

\section{Cross-reactivity of the human polyclonal antibody response elicited by CIGB-247 to other VEGF family members}

Human VEGF-A isoform 121 has a similar length to mature forms of human VEGF-C (112-227) and human VEGF-D (89-205). The amino acid sequence similarity between VEGF-A and VEGF-C is $47 \%$, while this value is equals to $35 \%$ for VEGF-A and VEGF-D. In order to explore whether the VEGF-specific polyclonal antibody response recognizes VEGF-C or VEGF-D through their VEGF homology domain, two ELISA formats were developed.

When hVEGF-C $\mathrm{CHO}_{\mathrm{O}}$ is captured with a monoclonal antibody specific to myc-tagged proteins, the optical density observed for PCS and NCS was similar between them (Fig. 5a). However, VEGF-C ${ }_{\text {CHO }}$ was 
recognized by their cognate receptors: VEGFR2 and VEGFR3. As expected, there was no binding for VEGFR1 and Bevacizumab (Figure 5a). To check the "functionality" of this form of ligand presentation in ELISA, hVEGF ${ }_{\mathrm{CHO}}$ was evaluated at the same ELISA conditions, and VEGF was recognized by PCS, Bevacizumab and their cognate receptors VEGFR1 and VEGFR2. As expected, there was no binding for VEGFR3 (Fig. 5a).

When hVEGF-C ${ }_{\mathrm{CHO}}$ is captured through its histidine tag using nickel coated high sensitivity multiwell plates, it was recognized by VEGFR3; however, the binding detected for IgG comp was lower than the binding observed for IgG neg (Fig. 5b). Similar results were obtained for commercially available VEGF-C and VEGF-D. The functionality of this ELISA format was checked using hVEGF $\mathrm{CHO}_{\mathrm{O}}$ at the same conditions. As expected, VEGF was recognized by IgG comp, and there was no binding for VEGFR3 (Fig. $5 b)$.

The results obtained here indicate that CIGB-247 elicits a polyclonal antibody response highly specific for human VEGF, and this antibody response does not cross-react with human VEGF-C and human VEGFD.

\section{Unexplored relevant aspects on safety profile and immunogenicity of the therapeutic intervention with CIGB- 247}

As has been previously commented, CUP of CIGB-247 allowed the evaluation of cancer patients with lifethreatening diseases, who do not meet entry criteria applied for CENTAURO and CENTAURO-2 clinical trials. Table 2 depicts different clinical conditions of cancer patients that represent new and challenging scenarios for the therapeutic intervention with CIGB-247.

Adverse events, probably or definitively related to the vaccine were not reported in immunized cancer patients with other chronic diseases including diabetes mellitus, arterial hypertension, cardiopathy, bronchial asthma or systemic lupus erythematosus (Table 2). Patients UC-CH22 and UC-HA01 were submitted to urgency surgery during their vaccination with CIGB-247; and they showed a normal recovery in terms of internal and external wound healing. Table 2 also indicates that CIGB-247 is able to induce a detectable VEGF-specific antibody response when chemotherapeutic agents, cytokines, monoclonal antibodies, immunosuppressant drugs and radiotherapy are applied simultaneously to the vaccination.

\section{Discussion}

So far, CIGB-247 can be considered the most advanced strategy worldwide targeting VEGF via active immunotherapy and the proposed mechanism of action for this intervention is related to the induction of a long lasting, self-regulated, nontoxic response of both humoral and cellular nature [13]. The immune 
response elicited by CIGB-247 has been extensively investigated in two phase I clinical trials (CENTAURO and CENTAURO-2), with follow up studies in long-term surviving patients [21-23]. As result of the clinical benefits observed in these long-term surviving patients [24], CUP of CIGB-247 was initiated with the aim to include cancer patients ineligible for clinical trials evaluating this vaccine candidate. Patients with different stages of their cancer disease, brain metastases, chronic diseases, autoimmune or immune suppressing diseases as well as patients receiving immune modulator drugs, chemotherapy or biological therapies were recruited. This initiative opened a promising cancer treatment opportunity for these patients, and also supplied further new information about antibody response and safety profile in subjects representative of the real-Cuban population of cancer patients.

This report confirms some of the results obtained from CENTAURO and CENTAURO-2 clinical trials, where CIGB-247 induced a polyclonal antibody response against human VEGF with a dual blocking activity on the interactions VEGF/VEGFR2 and VEGF/VEGFR1. This polyclonal antibody response was characterized by the presence of IgM, IgA and IgG antibodies specific to VEGF, being the latter the predominant immunoglobulin [22]. So far VEGF-specific IgE antibodies have not been detected in any of the studies of CIGB-247, and the presence of this class of immunoglobulin induced by active immunization has been reported in very few studies of therapeutic vaccines based on other antigens combined with other adjuvants [31,32]. Although IgE has been pointed out as important mediator of antitumor effect [33,34], probably, the generation of IgE antibodies by active immunization is the result of some adjuvants, vaccination schedules or both.

This work shows for the first time that CIGB-247 elicits a polyclonal antibody response with the ability to block the binding between VEGF and Bevacizumab, and this property is added to other previously described characteristic based on its capacity of inhibit the binding of VEGF to its receptors, VEGFR1 and VEGFR2 [22]. This VEGF-neutralizing activity is probably caused in a greater part to a steric hindrance, and to a lesser extent due to a competition for the same critical binding determinants on VEGF. This hypothesis is based on the fact that CIGB-247 uses as antigen a protein representative of human VEGF 121 isoform, in which amino acids R82, K84 and H86 were mutated to E in order to prevent possible undesired pro-angiogenic activities [18], and these three residues are reported as important binding determinants for the interactions VEGF/VEGFR2, VEGF/VEGFR1 and VEGF/Bevacizumab [35-39]. These mutations create a local conformational perturbation within the receptor binding domain of the antigen. Despite this, the polyclonal antibody response elicited after immunization blocks the receptor binding domain on natural VEGF as well as the binding site for Bevacizumab. The finding of the presence of Bevacizumab-blocking antibodies within the polyclonal response elicited by CIGB-247 indicates that the humoral response directed to VEGF could have a potentially relevant clinically activity. The induction of Bevacizumab-blocking antibodies by active immunization has been also developed by Wentink et al. This approach is based on vaccination against the Bevacizumab binding site on VEGF using a truncated protein (human VEGF $26-104$ ) as antigen and RFASE as adjuvant [16]. This VEGF therapeutic vaccine has shown antiangiogenic and antitumor activity in pre-clinical models [15], but discrete results in terms of immunogenicity have been observed in the first cancer patients treated with the vaccine [17]. 
The VEGF binding determinants for VEGFR2 and VEGFR1 overlap only partially, and their binding sites are located at opposite ends of VEGF [40]. On the other hand, it has been proposed that the neutralizing effect of Bevacizumab is based on steric hindrance and not due to competition for the same binding determinants on VEGF implicated on the interactions with VEGFR2 and VEGFR1 [39]. As has been previously commented, the polyclonal response generated after vaccination with CIGB-247 is able to impair the interaction of VEGF with these three molecules, which have different critical binding determinants. This experimental evidence indicates that the polyclonal response could be blocking a larger surface on VEGF as compared with the surface occupied by Bevacizumab. Whether this surface is being blocked by several antibody clones, with different affinities and avidities, the polyclonal antibodies could have a more effective VEGF neutralization than that of the monoclonal antibody. The polyclonality of the humoral response elicited by CIGB-247, as compared with monoclonal antibody Bevacizumab, could yield the same levels of VEGF blocking activity with a lower amount of specific antibodies. The benefits of a vaccine strategy over a monoclonal antibody approach have been demonstrated for an epidermal growth factor receptor 2 (HER 2)-based vaccine and monoclonal antibodies Trastuzumab and Pertuzumab [41], which have been approved for the treatment of HER 2 overexpressed breast cancers. The immunization with the extracellular domain of HER 2 (HER 2-ECD) elicits polyclonal antibodies with specificity for 14 different epitopes and with the ability to inhibit the binding of Trastuzumab and Pertuzumab [41, 42], which target different subdomains of HER 2-ECD. The properties exhibited by HER 2induced antibodies included higher growth inhibition and significant receptor internalization not observed when HER 2 overexpressing tumor cells were treated with Trastuzumab [41, 42]. To achieve a clinically relevant effect using a cancer vaccine, it is not only important to generate a robust immune response but also to sustain this response over time with booster vaccinations.

On this regard, patients recruited for CENTAURO and CENTAURO-2 clinical trials received off-trial monthly re-immunizations until death, intolerance, marked disease progression or patient's withdrawal of consent [21,22]. This re-immunization phase was important to sustain the immune response against VEGF, and as result of chronic immunization some patients showed clinical benefits [23, 24]. On this basis, all patients vaccinated with CIGB-247 under a compassionate use program were submitted to the same vaccination schedules. In line with our findings in the previous clinical studies, re-immunizations helped to preserve the seroconversion status and blocking activity in most of the patients. Booster vaccination has been broadly used for other cancer vaccines [31,43,44], indicating the importance of this strategy for the maintenance of immune response.

During repetitive vaccinations and the generation of an immune response, there is a programmed order of IgG subclass usage. Collins et al. have been proposed a sequential switch where B cells do a first switch from $\lg M$ to $\lg G 3$, then to $\lg G 1$ and to $\lg G 2$ and finally to $\lg G 4$, although the switch can also occur directly from IgM to a particular IgG subclass. For this mechanism the affinity maturation increases in the following order: IgG3<lgG1<lgG2<lgG4 [45]. The humoral response against VEGF elicited by CIGB-247 has been characterized by the presence of $\mathrm{IgG} 1$ as predominant subclass from the induction phase to one year of monthly re-immunizations [22]. IgG4 is the predominant immunoglobulin as result of long term vaccination up to 3 years [23]. Regarding IgG3, this subclass has a trend to disappear after one year 
of vaccinations; however it can be detected in some patients after three years of long term immunizations $[22,23]$. Most of these results have been confirmed in the present study. It is likely that the high affinity VEGF-specific IgG4 antibodies elicited after chronic vaccinations with CIGB-247 have an active role as effective blockers of the binding between VEGF and both receptors: VEGFR2 and VEGFR1. On the other hand, although IgG3 is considered a relatively transient immunoglobulin that is commonly associated with a primary immune response after initial exposure to an antigen [45], the detection of VEGF-specific IgG3 antibodies during the re-immunization phase could be explained by the generation of new $B$ cell clones ready to initiate a programed process of sequential switching. The generation of new $B$ cell clones during different time points of booster vaccination has been described by other investigators when two healthy donors were immunized with the tetanus toxoid (TT) vaccine [46]. The TT-specific serum IgG repertoire comprised new clonotypes after booster vaccination not observed before this, and their frequencies can vary between subjects.

Since 2011, a thoroughly characterization of the humoral response elicited by CIGB-247 in cancer patients has been performed [21-23], nevertheless no data about a possible cross-reactivity of the VEGFspecific polyclonal response with other VEGF family members is available. Herein presented results indicate that the antibody response induced by CIGB-247 is highly specific to VEGF. VEGF family is integrated by several members: VEGF-A, VEGF-B, VEGF-C, VEGF-D, and others less studied like VEGF-E and VEGF-F [47-49]. The amino acid sequence similarity between VEGF-A and VEGF-C or VEGF-D is $47 \%$ and $35 \%$ respectively. VEGF-A is a principal mediator of angiogenesis through its binding to VEGFR2, meanwhile VEGF-C and VEGF-D can also bind to the same receptor and exert their biological activity [50]. Despite CIGB-247 elicits a polyclonal antibody response specific to VEGF with blocking activity on the interaction between VEGF and VEGFR2, this antibodies do not cross-react with VEGF-C and VEGF-D. Similar results have been found for other cancer vaccines. For example, epidermal growth factor (EGF) and transforming growth factor-a (TGF- $a$ ) belong to EGF family, both soluble proteins are structurally related (between 30 and $40 \%$ amino acid homology) and exert its action after interaction with a common cell surface EGF receptor [51]. CIMAvax-EGF is a therapeutic vaccine able to induce a polyclonal antibody response directed to EGF, with the ability to block the interaction between EGF and EGF receptor. However, the presence of antibodies against TGF-a has not been detected within the elicited antibody response [52]. On the other hand, Hosseini-Ghatar and colleagues generated three polyclonal antibodies against HER 2-ECD and none of them were able to bind to the other members of the human HER family [41].

Other interesting findings obtained from this investigation is that CUP of CIGB-247 offers the first preliminary evidences of safety and immunogenicity of the vaccine candidate in cancer patients under clinical conditions not yet explored. In first place, cancer patients with chronic diseases or brain metastases were eligible to receive the vaccinations, being safe and well tolerated in all reported cases.

Secondly, it is well known that VEGF plays multiple roles in normal wound healing, and Bevacizumab treatment increases the risk of bleeding and wound healing complications in cancer patients [53]. Although a relatively low number of patients were submitted to major surgeries during vaccination with CIGB-247, no wound healing impairment was reported. This clinical observation could be explained by 
the incomplete abrogation of platelet VEGF levels after immunization with the vaccine candidate, where some VEGF levels remain circulating within platelets to maintain normal adult vasculature or other VEGFdependent normal physiological processes [27].

In third place, the finding that CIGB-247 is able to induce a safe and detectable VEGF-specific antibody response when other cancer therapies are applied simultaneously to the vaccination provides rationale to further investigate the combination of CIGB-247 with the standard of care for patients with different types of cancer. These treatments can include cytokines, monoclonal antibodies, immunosuppressant drugs, radiotherapy, chemotherapeutic agents or a combination thereof. Cytotoxic chemotherapeutic agents can make the tumor microenvironment markedly less immunogenic or less immunosuppressive $[54,55]$. The final effect may be dependent on cancer type, dosing strategy and the specific combinations of the cytotoxic drugs. During the clinical routine, chemotherapy is generally administered in regimens allowing the elicitation of normal immune responses by vaccines. This observation has helped to design combinations of conventional chemotherapeutics with vaccines [55]. In line with the notion that chemotherapies have the potential to enhance cancer vaccine-induced immune responses [56] and the preliminary evidences shown here, a phase II clinical trial was initiated, where advanced ovarian cancer patients are receiving neoadjuvant chemotherapy followed by interval debulking surgery, all this procedures in concomitancy with CIGB-247 (RPCEC00000246).

Taking into account all these results discussed here and the previous investigations about CIGB-247, this vaccine candidate is an effective "breaker" of the immune self-tolerance towards VEGF in unfavorable scenario such as cancer patients in advanced stages of their disease. This characteristic, the excellent safety profile and the potential combination with other therapies point to CIGB-247 as a promising therapeutic option for cancer treatment.

\section{Conclusions}

The present study confirms in a broader patient population that CIGB-247 is immunogenic, inducing IgM, $\lg A$ and $\lg G$ antibodies highly specific to human VEGF. This polyclonal response is able to block the interaction between VEGF and VEGFR1, VEGFR2 and Bevacizumab. The immunologic properties elicited during the induction phase are conserved at the re-immunization phase by monthly vaccinations. In both phases, VEGF-specific IgG1, IgG2, IgG3 and IgG4 subclasses were found, being IgG4 the predominant subclass after three years of chronic vaccination. In an extended perspective, the information unraveled by this study provide rationale for the application of CIGB-247 in cancer patients representative of the Cuban real clinical practice setting, and its potential combination with other cancer therapies.

\section{Declarations}

\section{Acknowledgments}


The present study had a collaboration group named as "Team of Investigators of compassionate use program". The names of the individual members are: Miladys Limonta Fernández (e-mail:

miladys.limonta@cigb.edu.cu, CIGB, Havana, Cuba); Sheila Padrón Morales (e-mail:

sheila.padron@cigb.edu.cu, CIGB, Havana, Cuba); Giselle Leal Alpízar (e-mail: aliciaal@infomed.sld.cu, CIMEQ, Havana, Cuba); Duneidis Godínez Díaz (e-mail: dugodinez@infomed.sld.cu, CIMEQ, Havana, Cuba); José Luis Rodríguez Reinoso (e-mail: jlr@cigb.edu.cu, CIGB, Havana, Cuba); Grettel Melo Suárez (email: grettel.melo@cigb.edu.cu, CIGB, Havana, Cuba); Verena Lucila Muzio González (e-mail: verena.muzio@cigb.edu.cu, CIGB, Havana, Cuba); Luis J. López Carrazana ("Celestino Hernández" Hospital, Villa Clara, Cuba); Ihosvany Enrique Carreño Rolando (e-mail: tazdecuba@nauta.cu, "Faustino Pérez" Hospital, Matanzas, Cuba); Yamirka Sánchez Ascuy (e-mail: yamirka72@nauta.cu, “Abel Santamaría" Hospital, Pinar del Río, Cuba).

\section{Funding}

This work was supported by Heber Biotec, and the Ministry of Public Health of Cuba. They were involved in all stages of the study conduct and analysis.

\section{Availability of data and materials}

All data generated or analyzed during this study are included in this published article in Figs. 1, 2, 3, 4 and 5; Tables 1 and 2; and in its Additional files 1, 2, 3, 4 and 5.

\section{Authors' contributions}

JS conceived and designed the experiments; performed the experiments; analyzed and interpreted the data; wrote the manuscript. YM and MB analyzed and interpreted the data, and reviewed the manuscript. FH designed the compassionate use program, was its main coordinator, and took part in data management, analyses and interpretation of the results. YM participated in monitoring, data acquisition and data management; KS and AT were the clinical investigators that recruited and treated the patients, and participated in the data collection. MP and LT took part in the trial coordination, interpretation of the results and reviewed the manuscript. MA was the project manager and took part in the data management and interpretation of the results. Team of Investigators of the compassionate use program were supplier of CIGB-247 antigen, coating antigen for ELISAs and were responsible for the care and welfare of the patients, as well as data acquisition. All authors read and approved the final manuscript.

\section{Authors' information}

Not applicable. 


\section{Ethics approval and consent to participate}

This study was conducted in accordance with the ethical guidelines of the Declaration of Helsinki and approved by the Cuban Regulatory Authority (CECMED). Written informed consent was obtained for all patients.

\section{Consent for publication}

Not applicable.

\section{Competing interests}

One author declares a financial competing interest. $\mathrm{MB}$ is the inventor on a patent application submitted by the Center for Genetic Engineering and Biotechnology that covers the use of the vaccine.

\section{References}

1. Ferrara $\mathrm{N}$ : The role of VEGF in the regulation of physiological and pathological angiogenesis. Exs 2005(94):209-231.

2. Rahimi N: VEGFR-1 and VEGFR-2: two non-identical twins with a unique physiognomy. Frontiers in bioscience : a journal and virtual library 2006, 11:818-829.

3. Li Y-L, Zhao H, Ren X-B: Relationship of VEGF/VEGFR with immune and cancer cells: staggering or forward? Cancer Biology \& Medicine 2016, 13(2):206-214.

4. Lapeyre-Prost A, Terme M, Pernot S, Pointet AL, Voron T, Tartour E, Taieb J: Immunomodulatory Activity of VEGF in Cancer. International review of cell and molecular biology 2017, 330:295-342.

5. Papadopoulos N, Martin J, Ruan Q, Rafique A, Rosconi MP, Shi E, Pyles EA, Yancopoulos GD, Stahl N, Wiegand SJ: Binding and neutralization of vascular endothelial growth factor (VEGF) and related ligands by VEGF Trap, ranibizumab and bevacizumab. Angiogenesis 2012, 15(2):171-185.

6. Cohen MH, Gootenberg J, Keegan P, Pazdur R: FDA drug approval summary: bevacizumab plus FOLFOX4 as second-line treatment of colorectal cancer. The oncologist 2007, 12(3):356-361.

7. Cohen MH, Gootenberg J, Keegan P, Pazdur R: FDA drug approval summary: bevacizumab (Avastin) plus Carboplatin and Paclitaxel as first-line treatment of advanced/metastatic recurrent nonsquamous non-small cell lung cancer. The oncologist 2007, 12(6):713-718.

8. Cohen MH, Shen YL, Keegan P, Pazdur R: FDA drug approval summary: bevacizumab (Avastin) as treatment of recurrent glioblastoma multiforme. The oncologist 2009, 14(11):1131-1138.

9. Summers J, Cohen MH, Keegan P, Pazdur R: FDA drug approval summary: bevacizumab plus interferon for advanced renal cell carcinoma. The oncologist 2010, 15(1):104-111. 
10. Tewari KS, Sill MW, Long HJ, Penson RT, Huang H, Ramondetta LM, Landrum LM, Oaknin A, Reid TJ, Leitao MM et al: Improved Survival with Bevacizumab in Advanced Cervical Cancer. The New England journal of medicine 2014, 370(8):734-743.

11. Pujade-Lauraine E, Hilpert F, Weber B, Reuss A, Poveda A, Kristensen G, Sorio R, Vergote I, Witteveen P, Bamias A et al: Bevacizumab combined with chemotherapy for platinum-resistant recurrent ovarian cancer: The AURELIA open-label randomized phase III trial. Journal of clinical oncology : official journal of the American Society of Clinical Oncology 2014, 32(13):1302-1308.

12. Wick W, Brandes AA, Gorlia T, Bendszus M, Sahm F, Taal W, Taphoorn MJB, Domont J, Idbaih A, Campone $\mathrm{M}$ et al: EORTC 26101 phase III trial exploring the combination of bevacizumab and lomustine in patients with first progression of a glioblastoma. Journal of Clinical Oncology 2016, 34(15_suppl):2001-2001.

13. Morera-Díaz Y, Gavilondo JV, Bequet-Romero M, Sánchez Ramírez J, Hernández-Bernal F, SelmanHousein K-H, Perez L, Ayala-Ávila M: Specific active immunotherapy with the HEBERSaVax VEGFbased cancer vaccine: From bench to bedside. Seminars in oncology 2018, 45(1):68-74.

14. Wang B, Kaumaya PT, Cohn DE: Immunization with synthetic VEGF peptides in ovarian cancer. Gynecologic oncology 2010, 119(3):564-570.

15. Wentink MQ, Hackeng TM, Tabruyn SP, Puijk WC, Schwamborn K, Altschuh D, Meloen RH, Schuurman T, Griffioen AW, Timmerman P: Targeted vaccination against the bevacizumab binding site on VEGF using 3D-structured peptides elicits efficient antitumor activity. Proceedings of the National Academy of Sciences of the United States of America 2016, 113(44):12532-12537.

16. Wentink MQ, Verheul HMW, Griffioen AW, Schafer KA, McPherson S, Early RJ, van der Vliet HJ, de Gruijl TD: A safety and immunogenicity study of immunization with hVEGF26-104/RFASE in cynomolgus monkeys. Vaccine 2018, 36(15):2025-2032.

17. Wentink MQ, van der Vliet HJ, De Gruijl TD, Griffioen AW, Verheul HMW: A phase I open-label clinical trial, evaluating the therapeutic vaccine hVEGF26-104/RFASE in patients with advanced solid tumors. 2019:134-147.

18. Morera Y, Bequet M, Ayala M, Lamdán H, Agger EM, Andersen P, Gavilondo JV: Anti-tumoral effect of active immunotherapy in C57BL/6 mice using a recombinant human VEGF protein as antigen and three chemically unrelated adjuvants. Angiogenesis 2008, 11(4):381-393.

19. Estévez F, Carr A, Solorzano L, Valiente O, Mesa C, Barroso O, Sierra GV, Fernández LE: Enhancement of the immune response to poorly immunogenic gangliosides after incorporation into very small size proteoliposomes (VSSP). Vaccine 1999, 18(1-2):190-197.

20. Bequet M, Morera Y, Ayala M, Ancízar J, Soria Y, Blanco A, Suárez-Alba J, Gavilondo JV: CIGB-247: a VEGF-based therapeutic vaccine that reduces experimental and spontaneous lung metastasis of C57BI/6 and BALB/c mouse tumors. Vaccine 2012, 30(10):1790-1799.

21. Gavilondo JV, Hernández F, Ayala M, de la Torre AV, de la Torre J, Morera Y, Bequet M, Sánchez J, Valenzuela CM, Martin $Y$ et al: Specific active immunotherapy with a VEGF vaccine in patients with 
advanced solid tumors. results of the CENTAURO antigen dose escalation phase I clinical trial. Vaccine 2014, 32(19):2241-2250.

22. Sánchez Ramírez J, Morera Díaz Y, Bequet-Romero M, Hernández-Bernal F, Selman-Housein Bernal KH, de la Torre Santos A, Santiesteban Álvarez ER, Martín Bauta Y, Bermúdez Badell CH, de la Torre Pupo $\mathrm{J}$ et al: Characteristics of the specific humoral response in patients with advanced solid tumors after active immunotherapy with a VEGF vaccine, at different antigen doses and using two distinct adjuvants. BMC immunology 2017, 18(1):39.

23. Morera $Y$, Sánchez J, Bequet-Romero $M$, Selman-Housein KH, de la Torre A, Hernández-Bernal F, Martin Y, Garabito A, Pinero J, Bermúdez $C$ et al: Specific humoral and cellular immune responses in cancer patients undergoing chronic immunization with a VEGF-based therapeutic vaccine. Vaccine 2017, 35(28):3582-3590.

24. Selman-Housein KH, de la Torre A, Hernández-Bernal F, Martin Y, Garabito A, Piñero J, Morera Diaz Y, Sánchez Ramírez J, Bequet-Romero M, Bermúdez $\mathrm{C}$ et al: Clinical benefits in patients with advanced solid tumors after long-term immunization with a VEGF therapeutic vaccine. Open Journal of Clinical and Medical Case Reports 2017, 3(2).

25. Al-Baimani K, Jonker H, Zhang T, Goss GD, Laurie SA, Nicholas G, Wheatley-Price P: Are clinical trial eligibility criteria an accurate reflection of a real-world population of advanced non-small-cell lung cancer patients? Curr Oncol 2018, 25(4):e291-e297.

26. CECMED: Requirements for the authorization of the expanded clinical use program for products subject to research. 2012. Available at: https://www.cecmed.cu/sites/default/files/adjuntos/Reglamentacion/Reg_63-2012.pdf

27. Sánchez Ramírez J, Bequet-Romero M, Morera Díaz Y, Hernández-Bernal F, Ayala Avila M: Does VEGF-targeted active immunotherapy induce complete abrogation of platelet VEGF levels? BMC research notes 2019, 12(1):323.

28. Sánchez Ramírez J, Bequet-Romero M, Morera Díaz Y, Hernández-Bernal F, de la Torre Santos A, Selman-Housein Bernal K-H, Martín Bauta Y, Bermúdez Badell CH, Limonta Fernández M, Ayala Avila M: Evaluation of methodologies to determine the effect of specific active immunotherapy on VEGF levels in phase I clinical trial patients with advanced solid tumors. Heliyon 2018, 4(11):e00906.

29. Sánchez Ramírez J, Morera Díaz Y, Musacchio Lasa A, Bequet-Romero M, Muñoz Pozo Y, Pérez Sánchez L, Hernández-Bernal F, Mendoza Fuentes O, Selman-Housein KH, Gavilondo Cowley JV et al: Indirect and competitive enzyme-linked immunosorbent assays for monitoring the humoral response against human VEGF. Journal of immunoassay \& immunochemistry 2016, 37(6):636-658.

30. Yang J, Yan J, Liu B: Targeting VEGF/VEGFR to Modulate Antitumor Immunity. Frontiers in immunology 2018, 9:978-978.

31. Staff C, Magnusson CG, Hojjat-Farsangi M, Mosolits S, Liljefors M, Frodin JE, Wahren B, Mellstedt H, Ullenhag GJ: Induction of IgM, IgA and IgE antibodies in colorectal cancer patients vaccinated with a recombinant CEA protein. Journal of clinical immunology 2012, 32(4):855-865. 
32. Kyogoku N, Ikeda H, Tsuchikawa T, Abiko T, Fujiwara A, Maki T, Yamamura Y, Ichinokawa M, Tanaka $\mathrm{K}$, Imai $\mathrm{N}$ et al: Time-dependent transition of the immunoglobulin $\mathrm{G}$ subclass and immunoglobulin $\mathrm{E}$ response in cancer patients vaccinated with cholesteryl pullulan-melanoma antigen gene-A4 nanogel. Oncology letters 2016, 12(6):4493-4504.

33. Platzer B, Elpek KG, Cremasco V, Baker K, Stout MM, Schultz C, Dehlink E, Shade KT, Anthony RM, Blumberg RS et al: IgE/FcepsilonRI-Mediated Antigen Cross-Presentation by Dendritic Cells Enhances Anti-Tumor Immune Responses. Cell reports 2015.

34. Fu SL, Pierre J, Smith-Norowitz TA, Hagler M, Bowne W, Pincus MR, Mueller CM, Zenilman ME, Bluth $\mathrm{MH}$ : Immunoglobulin $\mathrm{E}$ antibodies from pancreatic cancer patients mediate antibody-dependent cellmediated cytotoxicity against pancreatic cancer cells. Clinical and experimental immunology 2008 , 153(3):401-409.

35. Wiesmann C, Fuh G, Christinger HW, Eigenbrot C, Wells JA, de Vos AM: Crystal structure at 1.7 A resolution of VEGF in complex with domain 2 of the Flt-1 receptor. Cell 1997, 91(5):695-704.

36. Markovic-Mueller S, Stuttfeld E, Asthana M, Weinert T, Bliven S, Goldie KN, Kisko K, Capitani G, Ballmer-Hofer K: Structure of the Full-length VEGFR-1 Extracellular Domain in Complex with VEGF-A. Structure (London, England : 1993) 2017, 25(2):341-352.

37. Muller YA, Li B, Christinger HW, Wells JA, Cunningham BC, de Vos AM: Vascular endothelial growth factor: crystal structure and functional mapping of the kinase domain receptor binding site. Proceedings of the National Academy of Sciences of the United States of America 1997, 94(14):7192-7197.

38. Brozzo MS, Bjelic S, Kisko K, Schleier T, Leppanen VM, Alitalo K, Winkler FK, Ballmer-Hofer K: Thermodynamic and structural description of allosterically regulated VEGFR-2 dimerization. Blood 2012, 119(7):1781-1788.

39. Muller YA, Chen Y, Christinger HW, Li B, Cunningham BC, Lowman HB, de Vos AM: VEGF and the Fab fragment of a humanized neutralizing antibody: crystal structure of the complex at 2.4 A resolution and mutational analysis of the interface. Structure (London, England : 1993) 1998, 6(9):1153-1167.

40. Keyt BA, Nguyen HV, Berleau LT, Duarte CM, Park J, Chen H, Ferrara N: Identification of vascular endothelial growth factor determinants for binding KDR and FLT-1 receptors. Generation of receptorselective VEGF variants by site-directed mutagenesis. The Journal of biological chemistry 1996, 271(10):5638-5646.

41. Hosseini Ghatar R, Soltantoyeh T, Bahadori M, Khoshnoodi J, Golsaz Shirazi F, Jeddi Tehrani M, Amiri MM, Shokri F: Polyclonal Antibody against Different Extracellular Subdomains of HER2 Induces Tumor Growth Inhibition in vitro. Iranian journal of immunology : IJI 2017, 14(3):200-214.

42. Clay TM, Osada T, Hartman ZC, Hobeika A, Devi G, Morse MA, Lyerly HK: Polyclonal immune responses to antigens associated with cancer signaling pathways and new strategies to enhance cancer vaccines. Immunologic research 2011, 49(1-3):235-247.

43. Caballero I, Aira LE, Lavastida A, Popa X, Rivero J, Gonzalez J, Mesa M, Gonzalez N, Coba K, LorenzoLuaces P et al: Safety and Immunogenicity of a Human Epidermal Growth Factor Receptor 1 (HER1)- 
Based Vaccine in Prostate Castration-Resistant Carcinoma Patients: A Dose-Escalation Phase I Study Trial. Frontiers in pharmacology 2017, 8:263.

44. Junco JA, Rodríguez R, Fuentes F, Baladrón I, Castro MD, Calzada L, Valenzuela C, Bover E, Pimentel E, Basulto R et al: Safety and Therapeutic Profile of a GnRH-Based Vaccine Candidate Directed to Prostate Cancer. A 10-Year Follow-Up of Patients Vaccinated With Heberprovac. Frontiers in oncology 2019, 9:49-49.

45. Collins AM, Jackson KJ: A Temporal Model of Human IgE and IgG Antibody Function. Frontiers in immunology 2013, 4:235.

46. Lavinder JJ, Wine Y, Giesecke C, Ippolito GC, Horton AP, Lungu OI, Hoi KH, DeKosky BJ, Murrin EM, Wirth MM et al: Identification and characterization of the constituent human serum antibodies elicited by vaccination. Proceedings of the National Academy of Sciences of the United States of America 2014, 111(6):2259-2264.

47. Ferrara N, Gerber HP, LeCouter J: The biology of VEGF and its receptors. Nature medicine 2003, 9(6):669-676.

48. Ogawa S, Oku A, Sawano A, Yamaguchi S, Yazaki Y, Shibuya M: A novel type of vascular endothelial growth factor, VEGF-E (NZ-7 VEGF), preferentially utilizes KDR/FIk-1 receptor and carries a potent mitotic activity without heparin-binding domain. The Journal of biological chemistry 1998, 273(47):31273-31282.

49. Yamazaki Y, Matsunaga Y, Tokunaga Y, Obayashi S, Saito M, Morita T: Snake venom Vascular Endothelial Growth Factors (VEGF-Fs) exclusively vary their structures and functions among species. The Journal of biological chemistry 2009, 284(15):9885-9891.

50. Rauniyar K, Jha SK, Jeltsch M: Biology of Vascular Endothelial Growth Factor C in the Morphogenesis of Lymphatic Vessels. Frontiers in bioengineering and biotechnology 2018, 6:7.

51. Yeh J, Yeh YC: Transforming growth factor-alpha and human cancer. Biomedicine \& pharmacotherapy = Biomedecine \& pharmacotherapie 1989, 43(9):651-659.

52. Garcia B, Neninger E, de la Torre A, Leonard I, Martinez R, Viada C, Gonzalez G, Mazorra Z, Lage A, Crombet T: Effective inhibition of the epidermal growth factor/epidermal growth factor receptor binding by anti-epidermal growth factor antibodies is related to better survival in advanced nonsmall-cell lung cancer patients treated with the epidermal growth factor cancer vaccine. Clinical cancer research : an official journal of the American Association for Cancer Research 2008, 14(3):840-846.

53. Zhang H, Huang Z, Zou X, Liu T: Bevacizumab and wound-healing complications: a systematic review and meta-analysis of randomized controlled trials. Oncotarget 2016, 7(50):82473-82481.

54. Samanta D, Park Y, Ni X, Li H, Zahnow CA, Gabrielson E, Pan F, Semenza GL: Chemotherapy induces enrichment of CD47(+)/CD73(+)/PDL1(+) immune evasive triple-negative breast cancer cells. Proceedings of the National Academy of Sciences of the United States of America 2018, 115(6):E1239-e1248. 
55. Galluzzi L, Buque A, Kepp O, Zitvogel L, Kroemer G: Immunological Effects of Conventional Chemotherapy and Targeted Anticancer Agents. Cancer cell 2015, 28(6):690-714.

56. Weir GM, Liwski RS, Mansour M: Immune Modulation by Chemotherapy or Immunotherapy to Enhance Cancer Vaccines. Cancers 2011, 3(3):3114-3142.

\section{Tables}

Table 1 Characteristics of the patients enrolled in the compassionate use program with evaluations of the humoral response.

\begin{tabular}{|c|c|c|}
\hline Characteristic & $\mathrm{n}$ & Percentage \\
\hline \multicolumn{3}{|l|}{ Age } \\
\hline$\geq 50$ & 30 & $73 \%$ \\
\hline$<50$ & 11 & $27 \%$ \\
\hline \multicolumn{3}{|l|}{ Sex } \\
\hline Female & 25 & $61 \%$ \\
\hline Male & 16 & $39 \%$ \\
\hline \multicolumn{3}{|l|}{ Primary tumor site ${ }^{a}$} \\
\hline Ovary & 9 & $22 \%$ \\
\hline Breast & 4 & $10 \%$ \\
\hline Colon & 3 & $7 \%$ \\
\hline Soft tissues & 3 & $7 \%$ \\
\hline Brain & 3 & $7 \%$ \\
\hline Lymphatic system & 3 & $7 \%$ \\
\hline Lung & 2 & $5 \%$ \\
\hline Kidney & 2 & $5 \%$ \\
\hline Uterus & 2 & $5 \%$ \\
\hline Rectum & 2 & $5 \%$ \\
\hline Others & 8 & $20 \%$ \\
\hline \multicolumn{3}{|l|}{ Metastasis ${ }^{b}$} \\
\hline With metastatic disease & 27 & $66 \%$ \\
\hline Without metastases & 14 & $34 \%$ \\
\hline \multicolumn{3}{|l|}{ Metastatic sites ${ }^{\mathrm{C}}$} \\
\hline Lung & 10 & $26 \%$ \\
\hline Lymph nodes & 7 & $18 \%$ \\
\hline Peritoneum & 5 & $13 \%$ \\
\hline Liver & 5 & $13 \%$ \\
\hline Bone & 4 & $10 \%$ \\
\hline Brain & 3 & $8 \%$ \\
\hline Ovary & 2 & $5 \%$ \\
\hline Others & 3 & $8 \%$ \\
\hline
\end{tabular}

Patients diagnosed with solid tumor or hematologic malignancy were included in the compassionate use program after complete all steps of the recruiting process. ${ }^{a}$ at the time of initial diagnosis; ${ }^{b}$ metastasis found at the time of enrollment; ${ }^{\mathrm{c}}$ metastatic sites found in 27 patients with metastatic disease. 
Table 2 Patients with different clinical conditions vaccinated with CIGB-247 and treated with different cancer therapies. 


\begin{tabular}{|c|c|c|c|c|}
\hline $\begin{array}{l}\text { Patient } \\
\text { code }\end{array}$ & Diagnosis & Metastases & Relevant information & $\begin{array}{l}\text { Immunogenicity/Safety } \\
\text { profile }\end{array}$ \\
\hline $\begin{array}{c}\mathrm{UC}- \\
\mathrm{CH} 47\end{array}$ & $\begin{array}{l}\text { Breast } \\
\text { carcinoma }\end{array}$ & Lung & $\begin{array}{c}\text { Cardiopathy patient that } \\
\text { received CIGB-247 simultaneous } \\
\text { with QT (Capecitabine and } \\
\text { Letrozol). }\end{array}$ & $\begin{array}{c}\text { Patient positive for anti- } \\
\text { VEGF antibody response. } \\
\text { Physician did not report } \\
\text { any negative incidence on } \\
\text { heart disease. }\end{array}$ \\
\hline $\begin{array}{l}\text { UC- } \\
\text { CH77 }\end{array}$ & $\begin{array}{l}\text { Breast } \\
\text { carcinoma }\end{array}$ & Bones & $\begin{array}{l}\text { Patient that received CIGB-247 } \\
\text { simultaneous with QT } \\
\text { (Capecitabine, Zoledronic acid) } \\
\text { and Trastuzumab }\end{array}$ & $\begin{array}{l}\text { Patient positive for anti- } \\
\text { VEGF antibody response. }\end{array}$ \\
\hline $\begin{array}{l}\text { UC- } \\
\text { CH49 }\end{array}$ & Ovary ADC & Peritoneum & $\begin{array}{l}\text { Patient that received CIGB-247 } \\
\text { simultaneous with QT (Docetaxel, } \\
\text { Carboplatin) }\end{array}$ & $\begin{array}{l}\text { Patient positive for anti- } \\
\text { VEGF antibody response. }\end{array}$ \\
\hline $\begin{array}{l}\text { UC- } \\
\text { HA03 }\end{array}$ & Ovary ADC & $\begin{array}{l}\text { Contralateral } \\
\text { ovary }\end{array}$ & $\begin{array}{l}\text { Patient that received CIGB-247 } \\
\text { simultaneous with QT (Paclitaxel, } \\
\text { Carboplatin) and G-CSF }\end{array}$ & $\begin{array}{l}\text { Patient positive for anti- } \\
\text { VEGF antibody response. }\end{array}$ \\
\hline $\begin{array}{l}\text { UC- } \\
\text { HA07 }\end{array}$ & Ovary ADC & $\begin{array}{l}\text { Contralateral } \\
\text { ovary }\end{array}$ & $\begin{array}{c}\text { Patient that received CIGB-247 } \\
\text { simultaneous with QT (Taxol, } \\
\text { Cisplatin) }\end{array}$ & $\begin{array}{l}\text { Patient positive for anti- } \\
\text { VEGF antibody response. }\end{array}$ \\
\hline $\begin{array}{l}\text { UC- } \\
\text { CQ108 }\end{array}$ & Bladder ADC & Lung & $\begin{array}{l}\text { Patient that received CIGB-247 } \\
\text { simultaneous with QT } \\
\text { (Gemcitabine, Carboplatin) }\end{array}$ & $\begin{array}{l}\text { Patient positive for anti- } \\
\text { VEGF antibody response. }\end{array}$ \\
\hline $\begin{array}{l}\text { UC- } \\
\text { CH10 }\end{array}$ & $\begin{array}{l}\text { Hodgking } \\
\text { lymphoma }\end{array}$ & LN & $\begin{array}{l}\text { Patient that received CIGB-247 } \\
\text { simultaneous with QT } \\
\text { (Procarbazine, Vincristine) and } \\
\text { prednisone }\end{array}$ & $\begin{array}{l}\text { Patient positive for anti- } \\
\text { VEGF antibody response. }\end{array}$ \\
\hline $\begin{array}{l}\text { UC- } \\
\text { CH11 }\end{array}$ & SCLC & $\begin{array}{l}\text { Neck, } \\
\text { contralateral } \\
\text { pulmonary } \\
\text { metastases }\end{array}$ & $\begin{array}{l}\text { Patient that received CIGB-247 } \\
\text { simultaneous with QT (Cisplatin, } \\
\text { Etoposide (VP-16), taxol, } \\
\text { vincristine) and G-CSF. }\end{array}$ & $\begin{array}{l}\text { Patient positive for anti- } \\
\text { VEGF antibody response. }\end{array}$ \\
\hline $\begin{array}{l}\text { UC- } \\
\text { CQ105 }\end{array}$ & Rectum ADC & - & $\begin{array}{l}\text { Vaccination with CIGB-247 was } \\
\text { applied simultaneous with QT } \\
\text { (Capecitabine) }\end{array}$ & $\begin{array}{l}\text { Patient positive for anti- } \\
\text { VEGF antibody response. }\end{array}$ \\
\hline $\begin{array}{l}\text { UC- } \\
\text { HA01 }\end{array}$ & $\begin{array}{l}\text { Peritoneum } \\
\text { carcinoma }\end{array}$ & - & $\begin{array}{l}\text { Patient that received CIGB-247 } \\
\text { simultaneous with QT (Docetaxel, } \\
\text { Paclitaxel) and submitted to a } \\
\text { major abdominal surgery } \\
\text { (phlegmon). }\end{array}$ & $\begin{array}{l}\text { Patient positive for anti- } \\
\text { VEGF antibody response. } \\
\text { Physician did not report } \\
\text { any negative incidence on } \\
\text { wound healing. }\end{array}$ \\
\hline $\begin{array}{l}\text { UC- } \\
\text { CH22 }\end{array}$ & $\begin{array}{l}\text { Breast } \\
\text { carcinoma }\end{array}$ & $\begin{array}{l}\text { Contralateral } \\
\text { breast and } \\
\text { LN }\end{array}$ & $\begin{array}{l}\text { After fifth vaccination with } \\
\text { CIGB-247, patient was submitted } \\
\text { to urgency surgery (right tubo- } \\
\text { ovarian abscess) and } \\
\text { immunization was not } \\
\text { interrupted. }\end{array}$ & $\begin{array}{l}\text { Patient positive for anti- } \\
\text { VEGF antibody response }{ }^{\text {a }} \\
\text { Physician did not report } \\
\text { any negative incidence on } \\
\text { wound healing. }\end{array}$ \\
\hline $\begin{array}{l}\text { UC- } \\
\text { HA14 }\end{array}$ & Ovary ADC & - & $\begin{array}{c}\text { Insulin-dependent diabetic } \\
\text { patient with oral administration } \\
\text { of metformin }\end{array}$ & $\begin{array}{l}\text { Patient positive for anti- } \\
\text { VEGF antibody response. } \\
\text { Physician did not report } \\
\text { any negative incidence on } \\
\text { diabetes condition. }\end{array}$ \\
\hline
\end{tabular}




\begin{tabular}{|c|c|c|c|c|}
\hline $\begin{array}{l}\text { Patient } \\
\text { code }\end{array}$ & Diagnosis & Metastases & Relevant information & $\begin{array}{l}\text { Immunogenicity/Safety } \\
\text { profile }\end{array}$ \\
\hline $\begin{array}{l}\mathrm{UC}- \\
\mathrm{CH} 48\end{array}$ & $\begin{array}{c}\text { Ovary } \\
\text { carcinoma }\end{array}$ & $\begin{array}{l}\text { Liver, brain, } \\
\text { peritoneum }\end{array}$ & $\begin{array}{l}\text { Patient diagnosed with diabetes } \\
\text { mellitus }\end{array}$ & $\begin{array}{l}\text { Patient positive for anti- } \\
\text { VEGF antibody response. } \\
\text { Physician did not report } \\
\text { any negative incidence on } \\
\text { diabetes condition. }\end{array}$ \\
\hline $\begin{array}{l}\text { UC- } \\
\text { CH08 }\end{array}$ & $\begin{array}{l}\text { Malignant } \\
\text { pleural } \\
\text { mesothelioma }\end{array}$ & - & $\begin{array}{l}\text { Cardiopathy patient with } \\
\text { diabetes mellitus }\end{array}$ & $\begin{array}{l}\text { Patient positive for anti- } \\
\text { VEGF antibody response. } \\
\text { Physician did not report } \\
\text { any negative incidence on } \\
\text { chronic diseases. }\end{array}$ \\
\hline $\begin{array}{l}\text { UC- } \\
\text { CH38 }\end{array}$ & Osteosarcoma & Lung & $\begin{array}{l}\text { Patient with controlled-chronic } \\
\text { bronchial asthma }\end{array}$ & $\begin{array}{l}\text { Patient positive for anti- } \\
\text { VEGF antibody response. }\end{array}$ \\
\hline $\begin{array}{l}\mathrm{UC}- \\
\mathrm{CH} 25\end{array}$ & $\begin{array}{c}\text { Cervix } \\
\text { carcinoma }\end{array}$ & $\begin{array}{l}\text { Liver and } \\
\text { bones }\end{array}$ & $\begin{array}{l}\text { Patient diagnosed with systemic } \\
\text { lupus erythematosus }\end{array}$ & $\begin{array}{l}\text { Patient positive for anti- } \\
\text { VEGF antibody response. } \\
\text { Physician did not report } \\
\text { any negative incidence on } \\
\text { autoimmune disease. }\end{array}$ \\
\hline $\begin{array}{l}\text { UC- } \\
\text { CH46 }\end{array}$ & $\begin{array}{l}\text { Thyroid } \\
\text { carcinoma }\end{array}$ & LN and lung & $\begin{array}{l}\text { Patient that received CIGB-247 } \\
\text { simultaneous with oral } \\
\text { levothyroxine }\end{array}$ & $\begin{array}{l}\text { Patient positive for anti- } \\
\text { VEGF antibody response. }\end{array}$ \\
\hline $\begin{array}{l}\text { UC- } \\
\text { CQ116 }\end{array}$ & RCC & Lung & $\begin{array}{l}\text { Patient that received CIGB-247 } \\
\text { simultaneous with recombinant } \\
\text { IFN- } \alpha 2 \mathrm{~b}\end{array}$ & $\begin{array}{l}\text { Patient positive for anti- } \\
\text { VEGF antibody response. }\end{array}$ \\
\hline $\begin{array}{l}\text { UC- } \\
\text { CQ111 }\end{array}$ & GBM & - & $\begin{array}{l}\text { Patient that received CIGB-247 } \\
\text { simultaneous with RT }\end{array}$ & $\begin{array}{l}\text { Patient positive for anti- } \\
\text { VEGF antibody response. }\end{array}$ \\
\hline
\end{tabular}

${ }^{(a)}$ : Patient positive for anti-VEGF antibody response is referred to subjects that showed at least one serum sample with antibodies specific to VEGF or with VEGF blocking activity detected during induction or re-immunization phases. ADC: adenocarcinoma; QT: chemotherapy; LN: lymph nodes; RT: radiotherapy; G-CSF: granulocyte-colony stimulating factor; SCLC: small cell lung cancer; GBM: Glioblastoma multiforme; RCC: Renal cell carcinoma; IFN: Interferon.

\section{Figures}



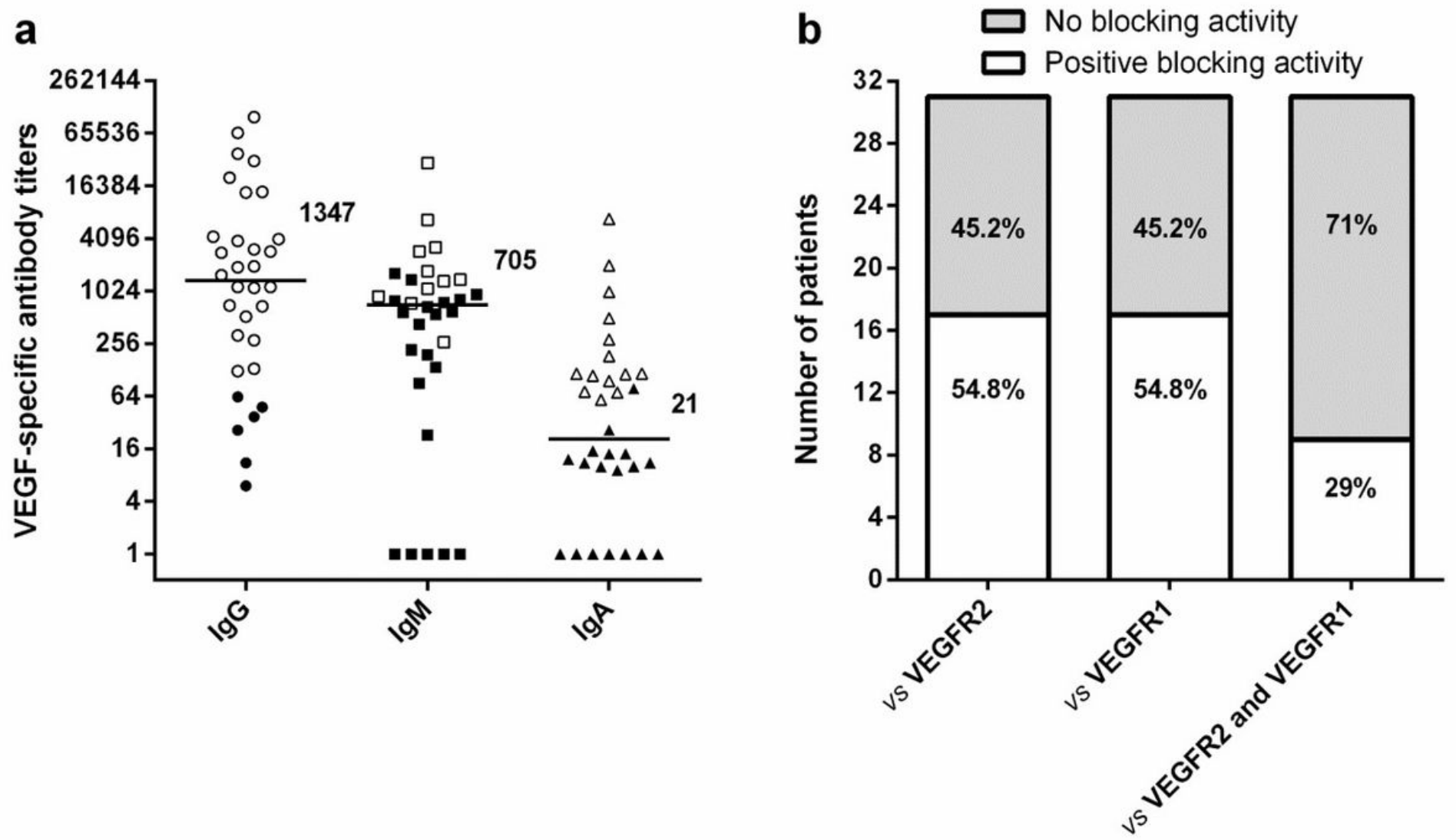

Figure 1

Classes of immunoglobulins specific to VEGF and blocking activity in vaccinated patients during induction phase. (a) IgG, IgM and IgA specific antibody titers expressed as reciprocal value. Prevaccination antibody titer (week 0 ) was subtracted from the post-vaccination antibody titer (VEGFspecific antibody titer). Horizontal bars represent the median of specific antibody titer, which are shown for each class of immunoglobulin with its corresponding value. Empty or filled symbols represent patients with positive or negative serum sample, respectively. To declare a given sample taken during vaccination to be positive for antibody, equations $A$ and $B$ were used (b) Blocking activity on the interactions VEGF/VEGFR2 or VEGF/VEGFR1 or both. Patients that has shown at least one serum sample with neutralizing anti-VEGF antibodies were considered with a positive blocking activity. To declare a given sample taken during vaccination to be positive, equation $\mathrm{D}$ was used. 


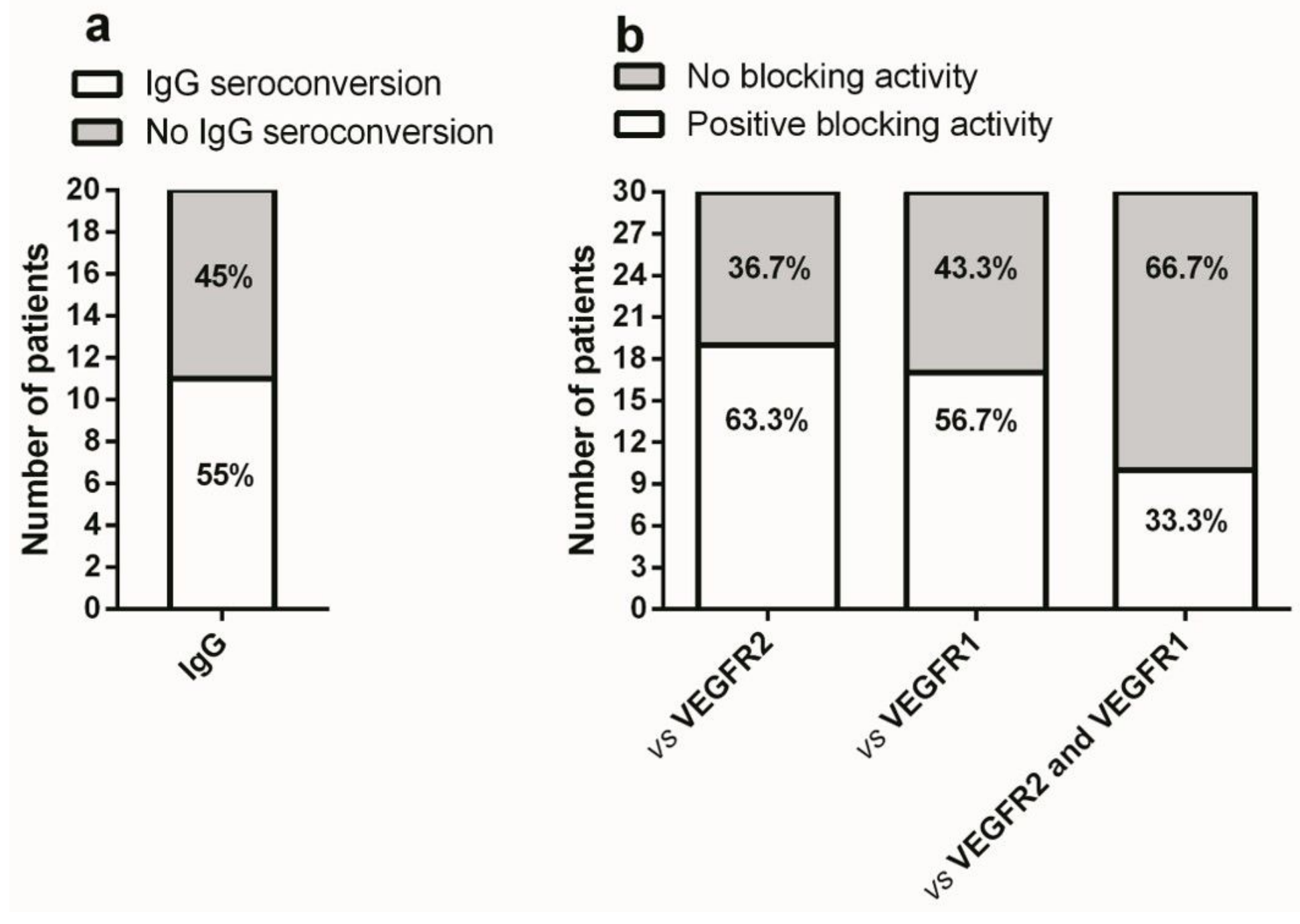

Figure 2

Anti-VEGF IgG seroconversion study and serum blocking activity in vaccinated patients during reimmunization phase. (a) Seroconverted patients (individual that has shown two or more samples positive for VEGF-specific IgG antibodies). (b) Blocking activities on the interactions VEGF/VEGFR2 or VEGF/VEGFR1 or both. Patients that has shown at least one serum sample with neutralizing anti-VEGF antibodies were considered with a positive blocking activity. 


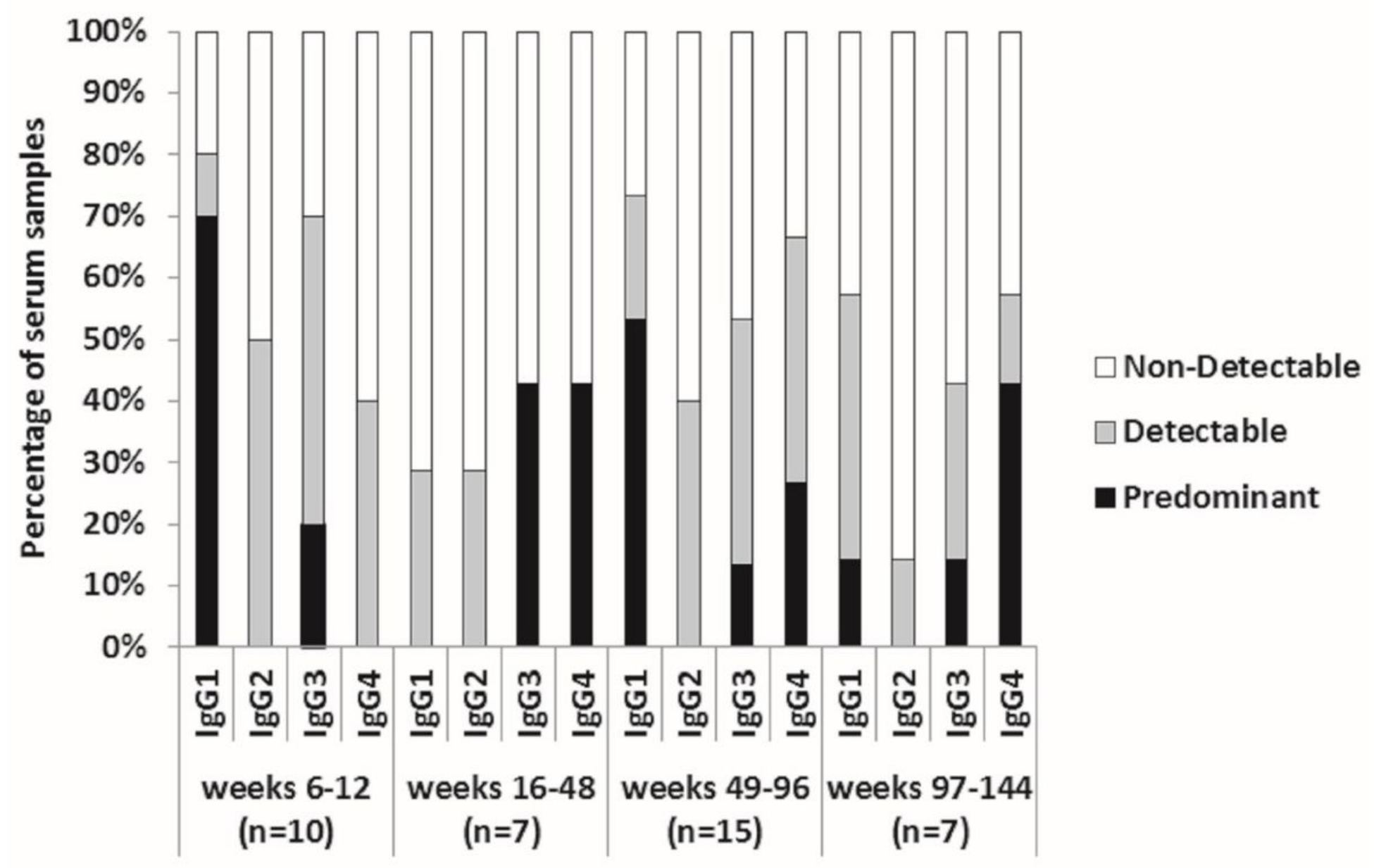

Figure 3

VEGF-specific IgG subclasses between weeks 6-12, 16-48, 49-96 and 97-144. The study was made for the available serum samples classified as positive for VEGF-specific IgG antibodies. " $n$ " represents the number of the available serum samples. Terms "non-detectable", "detectable" and "predominant" are detailed in Methods. 
a
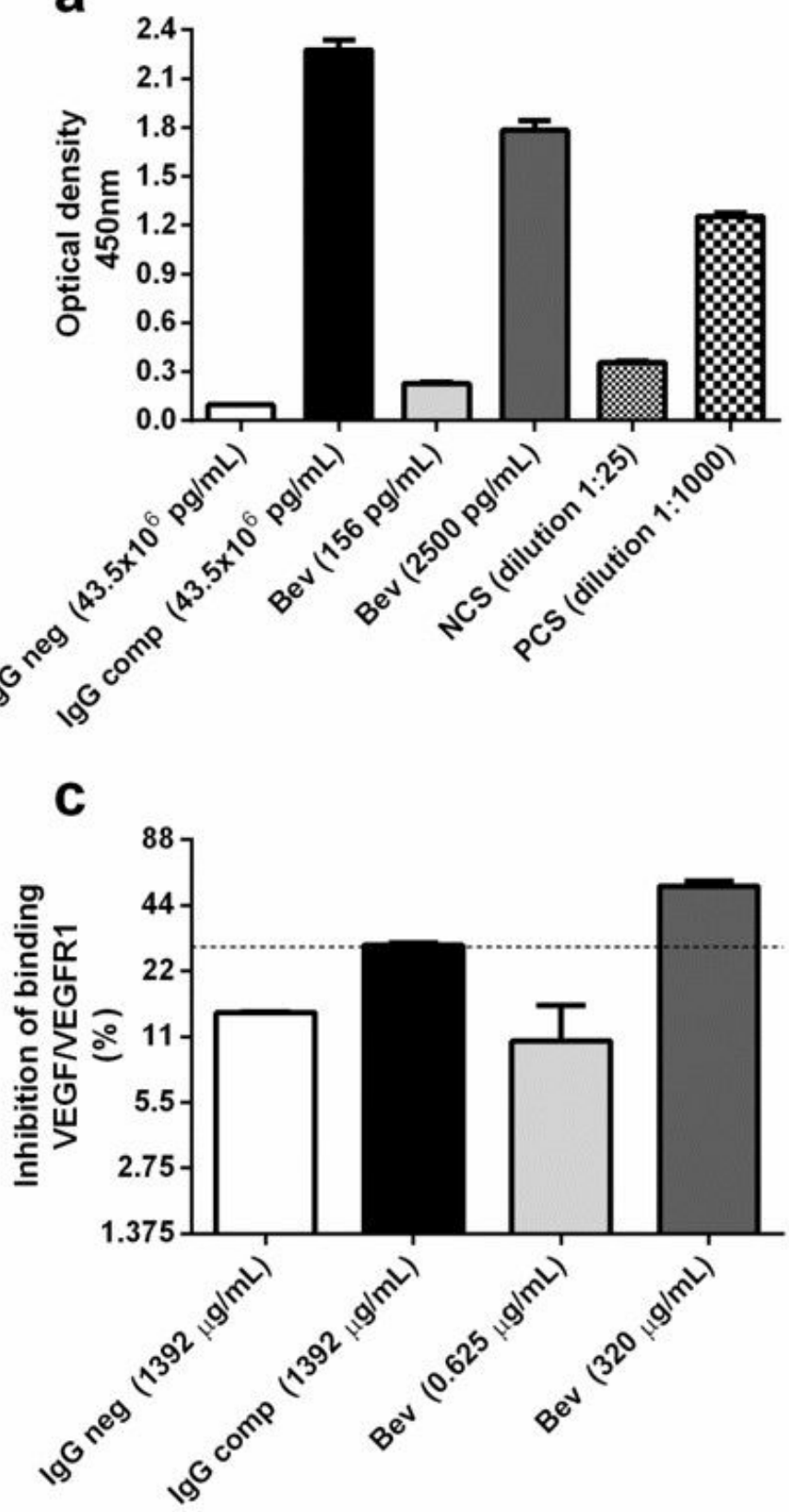

b

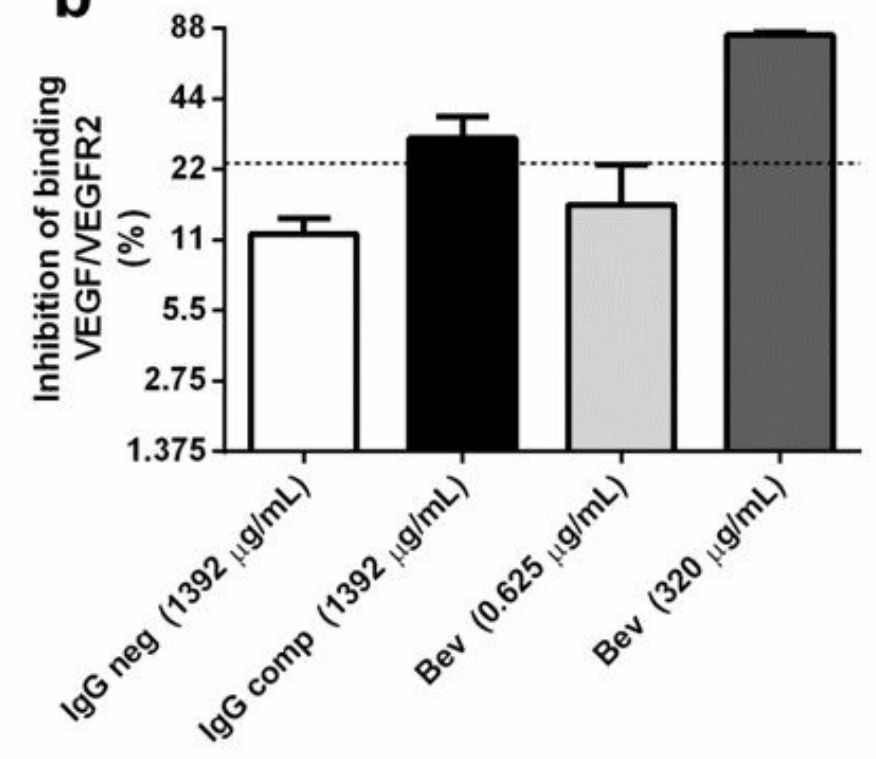

d

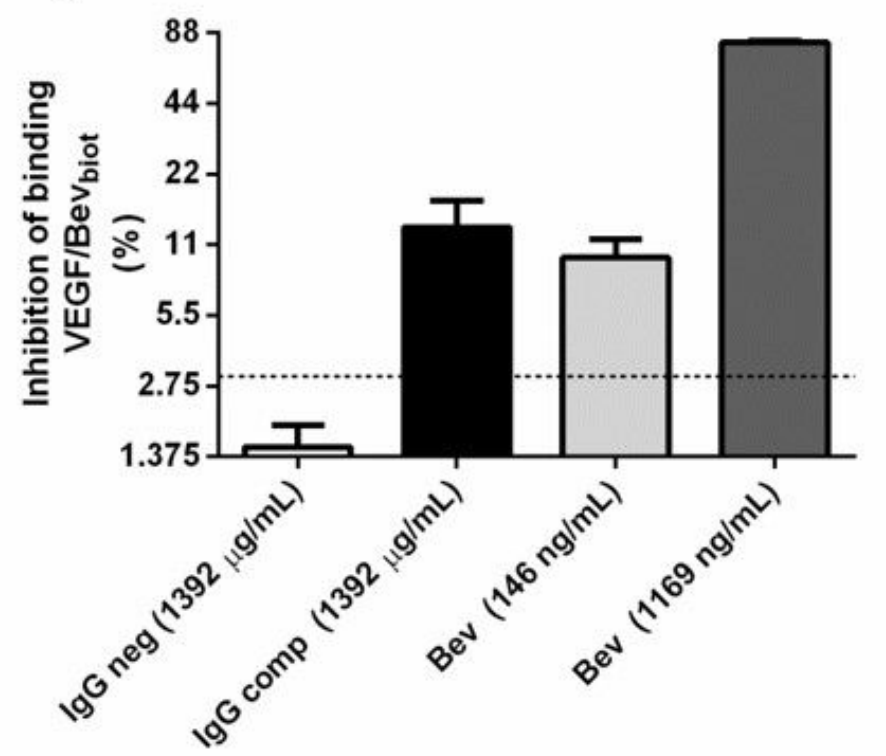

Figure 4

Immunologic properties of the IgG fraction purified from de serum of vaccinated patients (IgG comp). (a) Binding of IgG to VEGF-coated wells. Test samples were added to VEGF-coated wells and IgG bound to wells was detected with HRP-conjugated goat anti-human IgG antibody. This assay used as positive controls a human serum positive for VEGF-specific IgG antibodies (PCS) and Bevacizumab (Bev). Assay negative controls were a human serum negative for VEGF-specific IgG antibodies (NCS) and a purified human IgG isolated from pooled normal human serum (IgG neg) (b) Inhibition of the VEGF/VEGFR2 interaction. Test samples and VEGFR2-Fcy were added to VEGF-coated wells, and VEGF/VEGFR2-FcY binding was determined with biotin-conjugated anti-VEGFR2 antibody followed by streptavidinperoxidase conjugate (c) Inhibition of the VEGF/VEGFR1 interaction. Test samples and VEGFR1-Fcy were 
added to VEGF-coated wells, and VEGF/VEGFR1-Fcy binding was determined with biotin-conjugated antiVEGFR1 antibody followed by streptavidin-peroxidase conjugate (d) Inhibition of the VEGF/Bevacizumab interaction. Test samples and biotinylated Bevacizumab (Bev biot) were added to VEGF-coated wells, and VEGF/Bev biot binding was determined with streptavidin-peroxidase conjugate. Discontinued lines represent cut-off values that define the positivity for VEGF/VEGFR2, VEGF/VEGFR1 or VEGF/Bev blockade. The ability of test samples to block these three interactions was expressed as percentage of reduction of the maximum binding. Bev was used as inhibition positive control. IgG comp and IgG neg were evaluated in all ELISAs at the same total $\lg G$ concentration. All figures show the response obtained for IgG comp that exhibited the best ratio IgG comp/lgG neg. Column bars represent the means of three replicates and error bars represent standard deviations.
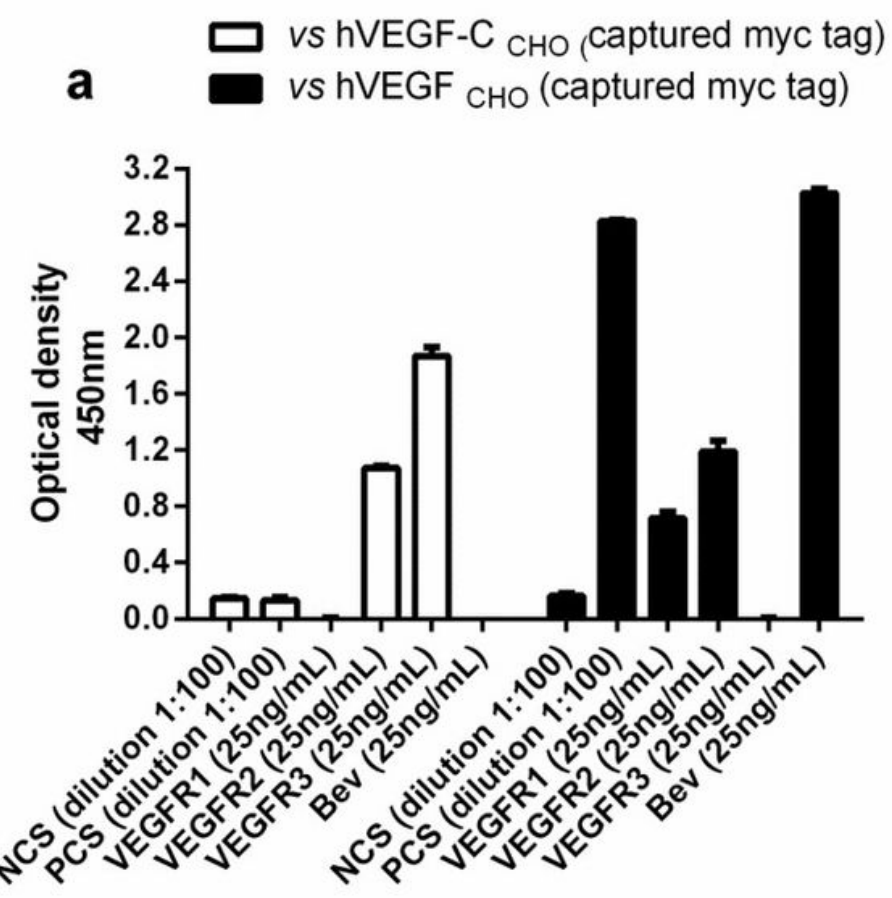

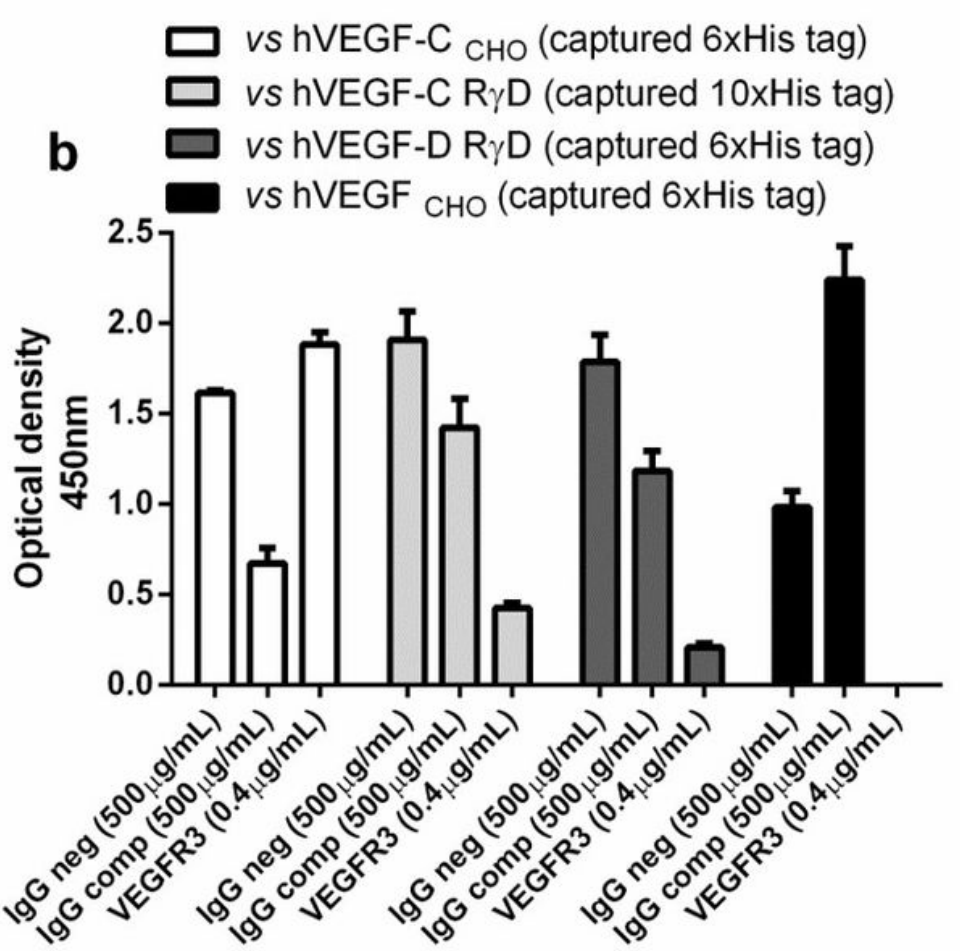

\section{Figure 5}

Binding experiments using as ligands human VEGF-C, human VEGF-D and human VEGF. (a) Binding to VEGF-C or VEGF of different types of samples with specificity for VEGF. Myc-tagged proteins, VEGF-C or VEGF obtained from $\mathrm{CHO}$ cells (hVEGF-C CHO or hVEGF CHO, respectively), were captured using coated wells with a monoclonal antibody specific to myc-tagged proteins. Test samples were added and the binding of IgG or VEGFR1-Fcy or VEGFR2- Fcy or VEGFR3-Fcy was detected with HRP-conjugated goat anti-human IgG antibody. This assay used as test samples a human serum positive for VEGF-specific IgG antibodies (PCS) and a human serum negative for VEGF-specific IgG antibodies (NCS). Control assays were Bevacizumab (Bev) and VEGFR1, VEGFR2 and VEGFR3. (b) Histidine-tagged proteins (hVEGF-C CHO, hVEGF CHO, or commercially available VEGF-C and VEGF-D) were captured using nickel coated multiwell plates. Test samples were added and the binding of IgG or VEGFR1-Fcy or VEGFR2- Fcy or VEGFR3-FcY was detected with HRP-conjugated goat anti-human IgG antibody. This assay used as test samples a 
human IgG purified from a pool of serum belonging to patients classified with positive VEGF-specific IgG antibodies (IgG comp) and a human IgG isolated from pooled normal human serum (IgG neg). This assay used as control VEGFR3. Column bars represent the means of three replicates and error bars represent the standard deviations.

\section{Supplementary Files}

This is a list of supplementary files associated with this preprint. Click to download.

- AdditionalFile4.docx

- AdditionalFile3.docx

- AdditionalFile2.docx

- eq2.jpg

- AdditionalFile1.docx

- AdditionalFile5.xlsx

- eq1.jpg 